NBER WORKING PAPER SERIES

THE CONSEQUENCES OF RADICAL REFORM:

THE FRENCH REVOLUTION

\author{
Daron Acemoglu \\ Davide Cantoni \\ Simon Johnson \\ James A. Robinson \\ Working Paper 14831 \\ http://www.nber.org/papers/w14831 \\ NATIONAL BUREAU OF ECONOMIC RESEARCH \\ 1050 Massachusetts Avenue \\ Cambridge, MA 02138 \\ April 2009
}

We thank Jared Diamond, Robert Dixon, Niall Ferguson, Tim Guinnane, Peter Hall, Philip Hoffman, Joel Mokyr, Sheilagh Ogilvie, Winifred Rothemberg, Jesus Villaverde, John Wallis, Peter Wilson and participants in the American Economic Association Annual Meeting for their comments, and Camilo García, Tarek Hassan, Jutta Hoppe and Michael Kapps for excellent research assistance. The views expressed herein are those of the author(s) and do not necessarily reflect the views of the National Bureau of Economic Research.

NBER working papers are circulated for discussion and comment purposes. They have not been peerreviewed or been subject to the review by the NBER Board of Directors that accompanies official NBER publications.

(C) 2009 by Daron Acemoglu, Davide Cantoni, Simon Johnson, and James A. Robinson. All rights reserved. Short sections of text, not to exceed two paragraphs, may be quoted without explicit permission provided that full credit, including $(\odot$ notice, is given to the source. 
The Consequences of Radical Reform: The French Revolution

Daron Acemoglu, Davide Cantoni, Simon Johnson, and James A. Robinson

NBER Working Paper No. 14831

April 2009

JEL No. N23

\begin{abstract}
$\underline{\text { ABSTRACT }}$
The French Revolution of 1789 had a momentous impact on neighboring countries. The French Revolutionary armies during the 1790s and later under Napoleon invaded and controlled large parts of Europe. Together with invasion came various radical institutional changes. French invasion removed the legal and economic barriers that had protected the nobility, clergy, guilds, and urban oligarchies and established the principle of equality before the law. The evidence suggests that areas that were occupied by the French and that underwent radical institutional reform experienced more rapid urbanization and economic growth, especially after 1850 . There is no evidence of a negative effect of French invasion. Our interpretation is that the Revolution destroyed (the institutional underpinnings of) the power of oligarchies and elites opposed to economic change; combined with the arrival of new economic and industrial opportunities in the second half of the 19th century, this helped pave the way for future economic growth. The evidence does not provide any support for several other views, most notably, that evolved institutions are inherently superior to those 'designed'; that institutions must be 'appropriate' and cannot be 'transplanted'; and that the civil code and other French institutions have adverse economic effects.
\end{abstract}

$\begin{array}{ll}\text { Daron Acemoglu } & \text { Simon Johnson } \\ \text { Department of Economics } & \text { Sloan School of Management } \\ \text { MIT, E52-380B } & \text { MIT } \\ \text { 50 Memorial Drive } & \text { E52-562 } \\ \text { Cambridge, MA 02142-1347 } & 50 \text { Memorial Drive } \\ \text { and NBER } & \text { Cambridge, MA 02142 } \\ \text { daron@mit.edu } & \begin{array}{l}\text { and NBER } \\ \text { sjohnson@ mit.edu }\end{array} \\ \text { Davide Cantoni } & \\ \text { Harvard University } & \text { James A. Robinson } \\ \text { Department of Economics } & \text { Harvard University } \\ \text { 1805 Cambridge Street } & \text { Department of Government } \\ \text { Cambridge, MA 02138 } & \text { N309, 1737 Cambridge Street } \\ \text { cantoni@ fas.harvard.edu } & \text { Cambridge, MA 02138 } \\ & \text { and NBER } \\ & \text { jrobinson@ gov.harvard.edu }\end{array}$




\section{Introduction}

The recent literature on comparative development has emphasized that underdevelopment is caused by institutions that do not create the right incentives for economic growth. But there is disagreement about which specific institutions are important. Some scholars emphasize property rights (North and Thomas, 1973, Acemoglu, Johnson and Robinson, 2001, Acemoglu and Johnson, 2005), some legal institutions (La Porta, Lopez-de-Silanes, Shleifer, and Vishny, 1998) and others barriers to entry or oligarchies (Olson, 1982, Acemoglu, 2008).

Another unresolved issue is whether institutions can be designed, and relatedly whether they can be reformed externally. Hayek (1960) argued that institutions cannot be designed and have to evolve organically (and that this was the major reason for the inferiority of the civil code), and a recent literature has claimed that institutions have to be 'appropriate' to the specific circumstances of countries (Berkowitz, Pistor and Richard, 2003a,b, Rodrik, 2007). ${ }^{1}$ These problems are amplified when such reforms are implemented 'Big Bang' style. Proponents of these views argue that enforced institutional change is likely to reduce prosperity, a claim that receives some support from the apparent failures of institutional reforms in Latin America, Africa, the former Soviet Union in the 1980s and 1990s, and the recent experiences in Afghanistan and Iraq. Not all external reform are failures, however, as evidenced, for example, by the successful US-imposed reforms in postwar Germany and Japan.

In this paper we exploit the variation in institutional reform created in Europe by the French Revolution to investigate the consequences of radical, externally-imposed reform on subsequent economic growth. After 1792 French armies invaded and reformed the institutions of many European countries. The lessons from this episode are central to some of the current debates on institutions. First, the package of reforms the French imposed on areas they conquered included the civil code, the abolition of guilds and the remnants of feudalism, and the introduction of equality before the law and the undermining of aristocratic privilege. These reforms thus clearly relate to the above-mentioned debates. If oligarchies were the main barrier to economic growth in Europe at the turn of the 19th century, then we would expect the Revolutionary reforms to unleash more rapid economic growth in affected areas. If, on the other hand, externallyimposed radical reform is generally costly or if the civil code creates major distortions, the

\footnotetext{
${ }^{1}$ Relatedly, a dominant paradigm in economics maintains that institutions efficiently — albeit slowly —adapt to the underlying characteristics of society (e.g., Demsetz, 1967, Djankov, Glaeser, La Porta, Lopez-de-Silanes and Shleifer, 2003).
} 
reforms should have negative effects. ${ }^{2}$

We investigate the economic consequences of the French Revolution, and particularly, the reforms that it imposed on the rest of Europe, by using two sources of historical data. The first is cross-national. French armies invaded and reformed some parts of Europe but not others, so we can take those invaded as the 'treatment group' and compare their relative economic success before and after the revolutionary period. Nevertheless, there is a substantial amount of heterogeneity in this sample. For instance, the French tended to have a greater impact on countries in Western Europe compared to Eastern Europe and even though we show that there is no evidence of pre-trends, this does not rule out potential unobserved differences between the treatment and control groups.

In addition to cross-national variation, we also examine variation within Germany. Parts of Germany, primarily the west and northwest, were invaded and reformed, while the south and the east were not. Therefore we can construct more comparable treatment and control groups within Germany. In addition, we collected data to develop several series of institutional reforms across German polities. This enables us both to verify that the French did indeed reform various aspects of institutions and to utilize a two-stage least squares strategy, with French invasion as an instrument for institutional reform.

Crucially for our identification strategy, European countries or parts of Germany did not choose the French institutions, but those institutions were imposed on them first by the Revolution and then by Napoleon. ${ }^{3}$ Moreover, territorial expansion by French armies did not target places with a greater future growth potential. Instead, it had two major objectives. The first was defensive, especially, in response to the threat of Austrian or Prussian (or later British) attempts to topple the Revolutionary regime. The second was expansionary. This was partly because of resource needs of the French Republic, and partly because of the ideology of the French Revolution. In addition, in the early 1790s, the French sought to establish France's 'natural frontiers.' ${ }^{4}$ Finally, the purpose of the institutional reforms of the French Revolution

\footnotetext{
${ }^{2}$ These issues are also related to the classic historical debate about the extent to which the institutions of the ancien régime impeded capitalism and economic growth and whether or not the French Revolution played a constructive or destructive role in European political development. The historical debate about the consequences of the French Revolution is also about its impact on political institutions and democracy, which is beyond the scope of the current paper.

${ }^{3}$ In most cases, there were local Jacobin (local radical) forces in the countries invaded by the French armies, but the presence of such forces did not play a major role in determining which countres and cities were invaded by the French. See, for example, Doyle (1989, Chapter 9).

${ }^{4}$ For example, the Revolutionary leader George Danton stated: "Les limites de la France sont marquées par la nature, nous les atteindrons des quatre coins de l'horizon, du côté du Rhin, du côté de l'Océan, du
} 
was not to foster industrialization per se, though they may have achieved this objective as a by-product of its major goal of destroying the grip of the aristocracy, oligarchy, and the clergy on political and economic power. ${ }^{5}$ Therefore, to a first approximation, we can think of the imposition of the institutions of the French Revolution as an 'exogenous treatment' and investigate the economic implications of the radical French reforms.

We distinguish three definitions of 'French treatment:' (1) length of French occupation (in years), (2) a dummy for French control during the Revolutionary period prior to the take-over of Napoleon in 9 November 1799 (18 Brumaire in the revolutionary calendar), (3) a dummy for French control during the Napoleonic period up until 1815. Using all three definitions, we find reduced-form evidence, both across countries and within Germany, that our main proxy for economic prosperity, urbanization rates, increased significantly faster in treated areas during the second half of the 19th century. We also supplement our cross-country analysis with Maddison's GDP data. Maddison reports data for 'Germany' and 'Italy' prior to their unification, rather than the independent polities which subsequently unified. Much of the variation in French treatment, however, is within what became Germany and Italy, so Maddison's data are much less appropriate than the urbanization data for our purposes. Nevertheless, the findings with GDP per-capita are similar, though on the whole weaker than those using urbanization rates.

Within Germany, we provide supporting evidence using the expansion of railways and the sectoral composition of employment, again suggesting that treated parts of Germany grew more rapidly - in fact, industrialized more rapidly — after 1850. Using German data, we further show a strong association between our measures of institutional reforms and French invasion or control. Using this association as a first stage, we also estimate instrumental-variables models, which indicate large effects of institutional reforms on subsequent growth. Overall, our results show no evidence that the reforms imposed by the French had negative economic consequences. On the contrary, there is fairly consistent evidence from a variety of different

côté des Alpes. Là, doivent finir les bornes de notre république." (speech to National Convention, January 31, 1793; quoted in Blanning 1983, p. 2). Grab (2003, p. 1) summarizes these motives and arguments as: "The revolutionary governments justified the occupation of foreign lands, using the theory of 'natural frontiers' and declaring their intention or liberating oppressed people from tyrannical regimes."

${ }^{5}$ It is unlikely that the reforms were made specifically to encourage industrial growth. Most likely, no one at the turn of the 19th century could have anticipated the new technologies that were to arrive a few decades later. The exception to this statement is textiles. By 1800 the British and others had established some new technologies that increased productivity (e.g., in spinning) by an order of magnitude. Textiles are an important part of the story in the Rhineland, discussed below, but there is no evidence that the French changed institutions in the Rhineland specifically because they foresaw great potential in the manufacture of cloth. 
empirical strategies that they had positive effects.

An important aspect of our findings is that the positive effects of institutional reforms are only visible in the second half of the 19th century. By 1850, treated areas show no differential growth or in some specifications, slight (and insignificant) negative growth. This is not surprising. The French reforms were accompanied by the disruptions caused by invasion and war and this often had quite destructive and exploitative aspects (see, for instance, Blanning, 1983, 1986). Grab (2003, p. 1), for example, writes "the French armies requisitioned provisions and imposed heavy war contributions on occupied regions, thereby alienating their populations." Thus, the short-term impact of French invasion may have been negative. But this is uninformative about the impact of Revolution-imposed institutional changes. The most plausible hypothesis - and our starting point - is that the major role of the reforms was in creating an environment conducive to innovation and entrepreneurial activity. This environment mattered most in the dissemination of the industrial revolution, which took place in Continental Europe in the second half of the 19th century. ${ }^{6}$ Our evidence of positive effects in the second half of the 19th century is consistent with this hypothesis.

There are several main conclusions from the evidence presented in this paper. First, the results emphasize the role of institutions and institutional reforms in economic development. ${ }^{7}$ Second, our findings are consistent with the view that the institutions of the ancien régime (guilds, feudal legacy in countryside, absence of equality before the law) impeded growth. However, the fact that French reforms came as a bundle does not allow us to assess the relative importance of, for example, the abolition of guilds compared to the abolition of feudal privileges. Third, they do not support the view that civil code and French institutions have detrimental economic effects. ${ }^{8}$ Fourth, the evidence does not support the thesis that insti-

\footnotetext{
${ }^{6}$ This argument is similar to that of Engerman and Sokoloff (1997) and Acemoglu, Johnson and Robinson (2002) who argue that the divergence of institutions in colonial societies, which took place between 1500 and 1800, had little economic impact until the age of industry.

${ }^{7}$ Also noteworthy is that unlike the experience of European colonialism in the wider world, the French did not settle after 1815 in the parts of Europe they reformed and they did not build schools, so during this episode there were large changes in institutions with culture, human capital and the ethnic composition of the population remaining largely unchanged.

${ }^{8}$ This statement is subject to two obvious caveats, firstly, that the comparison is not to the common law, and secondly, that it could be that the imposition of the civil code did have negative effects, but these were more than compensated for by positive effects emanating from reforms simultaneously implemented with the civil code. These caveats notwithstanding, if the civil code and other aspects of French institutions were highly damaging to growth, particularly if imposed on other countries, we would expect to find significant negative effects in treated areas. In addition, apart from parts of the world that voluntarily adopted the civil code, such as Latin America, existing evidence on the consequences of the civil code comes from former French colonies which, like the Europe we study, had the civil code imposed simultaneously with other French reforms.
} 
tutions are efficiently adapted to the underlying characteristics of a society and that evolved institutions are superior to those that are designed or externally imposed. The French Revolutionary armies imposed new and radically different institutions from those existing previously, and did so in extreme 'Big Bang' style. Nevertheless, our evidence suggests that this was an 'economic success'. Taken together, these findings are interesting for those who favor radical institutional reforms. They suggest these may be successful, at least in certain historical contexts.

The success of the French reforms raises the question: why did they work when other externally-imposed reforms often fail? Most likely this is because the reforms were much more radical than is typically the case. ${ }^{9}$ The French reformed simultaneously in many dimensions and weakened the powers of local elites, making a return to the status quo ante largely impossible. Even when some pre-revolution elites returned to power after 1815, there was a permanent change in the political equilibrium. This scope and radicalism of the French reforms are common with the post-war reform experiences in Germany and Japan and stand in contrast with many other reform experiences.

In addition to the literature on the implications and desirability of different types of institutional reforms, discussed above, our paper is related to a large literature on the consequences of the French Revolution. The debate on the French Revolution was started in its modern form by the pamphlet published by the conservative English philosopher Edmund Burke in 1790, entitled Reflections on the Revolution in France, which initiated controversies about institutional change which continue today. In this pamphlet, Burke condemned the brutality, the interventionist spirit and the radicalism of the French Revolution and argued:

"It is with infinite caution that any man should venture upon pulling down an edifice, which has answered in any tolerable degree for ages the common purposes of society, or on building it up again without having models and patterns of approved utility before his eyes" Burke (1969, p.152).

The conclusion Burke drew from these events was that the negative impacts of the French Revolution would be felt not only in France and not only in its immediate aftermath, but would potentially change the world for many more decades or even centuries to come.

On the other side, the positive reception of the French Revolution was as enthusiastic as Burke's condemnation. Thomas Paine, in a book that would subsequently become a classic for

\footnotetext{
${ }^{9}$ See Acemoglu and Robinson (2008) for a model in which limited reforms can be counterproductive.
} 
the democratization movements of the 19th-century Europe, The Rights of Man, responded to Burke in 1791. Paine hailed the French Revolution as the harbinger of freedom and equality before the law, a role that it achieved by demolishing the ancien régime. Paine argued:

"It was ... against the despotic principles of the government, that the nation revolted. These principles had ... become too deeply rooted to be removed, and the Augean stable of parasites and plunderers too abominably filthy to be cleansed, by anything short of a complete and universal revolution" Paine (1969, p. 69).

According to Paine, the French Revolution was exactly the kind of radical institutional reform necessary to break the hold on land and people exercised by the ancien régime, which was not only morally abhorrent, but also the source of significant economic inefficiencies. The Revolution would therefore pave the way for modern freedoms and democratic institutions by removing serfdom, aristocratic privileges, the Church's domination over politics and land, and inequity before the law.

The debate between Burke and Paine has not been resolved by academic research and there is no consensus about the economic consequences of the French Revolution. On the one hand, many economic historians, like Landes (1969, p. 142), view the French Revolution as "a political roadblock" to technological adoption for Continental countries, and conclude that as a consequence of the Revolution, "the gap in technique [between the Continent and Britain] had widened, while most of the fundamental educational, economic, and social obstacles to imitation remained" (Landes, 1969, p. 147). Similarly, Buyst and Mokyr (1990, p. 64, 74) write: "it is our contention ... that the Dutch economy in the years of the French and Napoleonic Wars was another example of a small open commercial economy whose prosperity was disrupted by world events ... The French period ... [was] disastrous for the Dutch economy." Crouzet's (2001, p. 121) view is similar, noting "the French Revolution and the wars that followed greatly slowed the transfer of technology." 10

\footnotetext{
${ }^{10}$ Within the history profession the economic impact of the French Revolution has become inexorably intertwined with the Marxist interpretation of the revolution as marking the 'rise of the bourgoisie'. Most historians now reject a Marxist interpretation of the Revolution, but have not articulated an alternative assessment of its implications. Other economic historians simply ignore the Revolution. In the literature on 19th century German industrialization, for example, though it is common to argue that the Stein-Hardenberg Reforms in Prussia after 1807, which were induced by the defeat of Prussia by Napoleon at Jena, helped to modernize agriculture and facilitate the reallocation of labor to industrial areas (e.g., Tilly, 1996), little mention is made of any potential impact of French institutional reforms in Germany. The institutional reform most mentioned is the formation of the Zollverein customs union in 1833.
} 
On the other hand, many other economic historians also agree with Mokyr's assessments that "the Revolution's long-term effect was to clear up the debris of the ancien régime on the Continent, thus assuring Europe's ability eventually to follow Britain in revolutionizing its productive system" (1990, p. 259), and that "the French Revolution and Napoleon installed more forward looking governments in Europe" (1990, p. 253). Even Landes, who generally emphasizes the negative effects of the Revolution, also mentions in passing that such institutional changes as the abolition of guilds were beneficial (1969, pp. 144-145). ${ }^{11}$

The rest of the paper is organized as follows. Section 2 provides an overview of the history of the French Revolution and the subsequent invasion of Europe by the French. Section 3 discusses our data. Section 4 provides country-level regression evidence investigating the reduced form effect of treatment on our dependent variables. Section 5 looks at the differences in the growth experience of treated and untreated German polities. Section 6 concludes.

\section{The Effect of the French Revolution on Europe}

In this section, we provide a brief sketch of certain aspects of the French Revolution and the situation in various neighboring countries and cities before the Revolution that are relevant to our investigation. We also recount how expansion by the French Revolutionary armies and later by Napoleon affected these areas. ${ }^{12}$ Further historical details are provided in Acemoglu, Cantoni, Johnson and Robinson (2009).

The Revolution was precipitated by a long-running fiscal crisis which led to the convening of the Estates-General in 1789 for the first time since 1614. The initial meeting of the EstatesGeneral in Versailles on May 5, 1789 ended with the decision to convene a more powerful body, the National Assembly, which initiated a process of radicalization culminating in the storming of the Bastille on July 14, 1789. The newly-formed National Constituent Assembly abolished feudalism and all of the special privileges and rights of the First and Second Estates on August 4, 1789. This was followed by the abolition of the Church's authority to levy special taxes, and later turning the clergy into employees of the state, thus starting the process of the separation of church and state. It subsequently passed a constitution on September 29, 1791,

\footnotetext{
${ }^{11}$ See also Crouzet (2001, p. 122), Cameron (1993, pp. 211-213) and Rosenthal (1992). Similarly, Rudé (1964), Kisch (1962), Trebilcock (1981), Doyle (1989), or Grab (2003) also argue that the French reforms were significant improvements relative to the situation at the time. None of these works systematically investigates the economic consequences of the Revolution either in the short or the long run.

${ }^{12}$ This section draws on Doyle (1989), Palmer (1959, 1964), Rudé (1988), Grab (2003), and Blanning (1983, 1986, 1996).
} 
making France a constitutional monarchy. This constitution also removed the major power of the guilds in the cities.

The radicalization of the Revolution led to the Terror which ended with the execution of Robespierre and Saint-Just in July 1794. There followed a phase of relative stability, first in the form of collective government under the Directory between 1795 and 1799, and then with more concentrated power in the form of a three person Consulate, consisting of Ducos, Sieyes and Napoleon Bonaparte. Already during the directory, the young general Bonaparte had become famous for his military successes and statesmanship. His influence was only to grow after 1799. The Consulate soon became personal rule by Napoleon, who initially engineered his election as First Consul in November 1799 with the coup of the 18th of Brumaire and then declared himself emperor in 1804. The years between 1799 and the end of Napoleon's reign, 1815, witnessed a series of great victories, including those at Austerlitz, Jena-Auerstedt, and Wagram, bringing continental Europe to its knees. They also allowed Napoleon to impose his will (and his legal code) across a wide swath of territory.

\subsection{Europe Before the Revolution}

Before the age of the French Revolution, much of Europe was dominated by two kinds of oligarchies, the landed nobility in agriculture and the urban-based oligarchy controlling commerce and various occupations, with explicit or implicit entry barriers.

By the end of the eighteenth century, feudalism in its most rigid form had disappeared in many parts of Europe, but a lot of its remnants remained. Serfdom - the system through which peasants are tied to the land and cannot sell their labor in free markets or engage in other occupations without the permission of landowners - still continued in much of Eastern Europe (see Blum, 1978), while it had been replaced by various forms of taxes and tributes to landowners in other areas, which could nonetheless be quite onerous. ${ }^{13}$ For example, in the Rhineland, the first area in Germany to come under French control, an attenuated form of serfdom (Grundherrschaft) which severely restricted freedom of movement was still practiced (Blanning 1983, pp. 20-21). Grab (2003, p. 86) states: "Their conditions were worse east of the Elbe where serfdom still prevailed. But even in many western regions where serfdom had declined and peasants were freer and better off, they were often still subject to landlords to

\footnotetext{
${ }^{13}$ Since one could be concerned that including Eastern Europe in the sample leads the control group to be very heterogeneous, in the empirical work we show that all our results hold when we restrict our sample to Europe West of the Elbe.
} 
whom they owed seigneurial fees and labor obligations. In addition they had to pay taxes and support their parishes and village communities."

Even when serfdom in its classic form was absent, various rights of the nobility and clergy created a very unequal political and economic situation in rural areas. These groups were frequently exempt from taxation by the state and enjoyed the right of taxation of the peasants under their control. Lenger (2004, p. 92), for example, describes this as: "besides the original obligations to provide services and dues to the lord the agricultural labor force was also burdened with personal servitude". He continues:

"In the small territory of Nassau-Usingen around 1800 there were no less than 230 different payments, dues, and services that the peasants living there had to provide to the lords. Dues included ... the 'blood tithe' to be paid after an animal was slaughtered, a 'bee tithe', a 'wax tithe' ... as well as large fees owed to the lord whenever a piece of property changed hands." (Lenger, 2004, p. 96).

Moreover, in places where some form of seigneurial privilege remained, it was usual for nobility and clergy to be subject to different laws and courts. The principle of equality before the law was quite alien (or even revolutionary) in most of Europe in 1789.

The urban oligarchy was perhaps even more pernicious to industrialization. Almost all major occupations were controlled by guilds, significantly limiting entry into those professions by others, and often restricting adoption of new technologies (see White, 2001, for examples from French guilds). For example, Cipolla (1970) argues that the guilds stopped innovation in Italy, in particular they forbade the production of exactly the type of lower quality goods that were taking their markets. In Venice (p. 206) "for almost the whole of the 17th century, the statutes of the guild prevented cloth from being made of the English and Dutch type, which had had so much success on the international markets. Moreover, the guild statutes not only demanded the production of a traditional type of goods, but also prevented the adoption of new methods of making these old products." Braudel's (1992, p. 136) and Rapp's (1976) analysis is similar. For the case of Germany, a similar argument is made by Ogilvie (2004, 2007) and Kisch (1989) for the Rhineland. In the major cities of Cologne and Aachen the adoption of new textile (spinning and weaving) machines were significantly delayed because of guild restrictions. In addition, many cities were controlled by a few families for many generations, amassing wealth at the expense of potential new entrants with greater ability or better technologies. 


\section{$2.2 \quad$ Under the Republic}

Despite the fact that the French Revolution was immediately seen as threatening to Europe's elite, war - the so-called War of the First Coalition - did not break out until $1792 .{ }^{14}$ Contrary to almost everyone's expectations, after some early defeats, the armies of the new Republic were victorious in an initially defensive war. There were serious organizational problems to overcome, but particularly after the introduction of mass conscription (the levée en masse) in August 1793, the French had a military advantage than verged on supremacy.

Initial military success encouraged the Republic's leadership to expand France's borders, with an eye towards creating an effective buffer between the new Republic and the hostile monarchs of Prussia and Austria. The French quickly seized present-day Belgium and the Netherlands (where ice famously allowed French cavalry to capture a large part of the Dutch navy). The French also gained effective control over much of modern-day Switzerland. In all three places, the French had strong control through the 1790s.

Germany was initially hotly contested but by 1795 the French had firm control over the Rhineland (the west or left bank of the Rhine), and the Prussians were forced to recognize this fact under the Treaty of Basle. ${ }^{15}$ Between 1795 and 1802, the French firmly held the Rhineland, but not any other part of Germany. In 1802 the Rhineland was officially incorporated into France.

Italy remained the main seat of war in the second half the 1790s, with the Austrians as the main opponents. Savoy was annexed by France in 1792, and a stalemate was reached until Napoleon's invasion in April 1796. In his first major continental campaign, by early 1797 Napoleon had swept up almost all of Northern Italy, except for Venice (which was taken by the Austrians). The Treaty of Campo Formio, signed with the Austrians in October 1797, ended the War of the First Coalition and recognized a number of French-controlled republics in Northern Italy.

However, the French continued to expand their control over Italy even after this treaty. In March 1798 the French invaded the Papal States and established the Roman Republic. In January 1799, Naples was conquered and the Parthenopean Republic created. ${ }^{16}$ With the

\footnotetext{
${ }^{14}$ The initial reaction in European capitals was amazement but there was no perceived need to intervene. This changed with the execution of Louis XVI. See Doyle (1989) for general background and Blanning (1986) for a more detailed treatment. Esdaile $(1995,2001)$ and Ellis (2003) are succinct overviews of all of the wars from 1792 to 1815, while Blanning (1996) and Gates (1997) provide more details.

${ }^{15}$ Part of the broader 1795 Peace of Basle with Prussia, Spain, and Hessen-Kassel.

${ }^{16}$ The Parthenopean Republic was short-lived, but the French were soon back and-under Napoleon-seem to
} 
exception of Venice (still Austrian), the French now controlled the entire Italian peninsular either directly (Savoy) or through satellite republics (Cisalpine, Ligurian, Roman, and Parthenopean). There was further back-and-forth in the War of the Second Coalition (1798-1801), but this ended with the French essentially remaining in control.

\subsection{Institutional Changes Induced by the Revolutionary Armies}

Many of the most radical institutional changes were undertaken during the invasion of the French Revolutionary armies. This included the abolition of all the remaining vestiges of serfdom and quasi-feudal land relations, the hold of the clergy over economic and political power, the domination of the guilds in urban areas, and legal changes establishing equality before the law.

In Belgium "The clergy and the nobility, the two upper estates, enjoyed many privileges and possessed considerable wealth and political power ... Urban guilds and corporations, the dominant element in the Third Estate, also possessed important privileges and controlled the towns" (Grab, 2003, p. 75). France annexed Belgium in 1795 and ruled for 20 years. Equality before the law was established and seigneurial rights, the tithe, noble privileges, and the guilds were abolished; in fact, from December 1796, any new French legislation became applicable in Belgium (Grab, 2003, p. 78).

In the Netherlands (or United Provinces), the existing institutions were more those of entrenched urban oligarchies in the various cities. These oligarchies were effectively expropriated by the French and, after considerable upheaval, the Batavian Republic was established along French lines (Grab, 2003, Chapter 4).

In Switzerland, the situation was similar to the Netherlands. Before 1789, "Feudal privileges persisted in many rural communities. Peasants owed the Church and landlords tithe, seigneurial fees, and labor services. Many Swiss lacked the freedom to settle where they wanted to or choose the occupation they desired." (Grab, 2003, p. 113). With the coming of Revolutionary armies, existing oligarchs were dispossessed or forced to cede power, and feudal privileges largely disappeared.

In Germany, the only real changes during this period were in the Rhineland (West Bank of the Rhine). While the impact of the French on the Rhineland during the 1790s remains controversial, especially because of the great deal of plunder and the resulting resentment by

have had a great impact on some institutions in the south of Italy, on which see Davis (1991, 2003) or Gregory (2001). 
the local population mentioned above (see, e.g., Blanning, 1983, Doyle, 1989), the importance of the revolutionary reforms in Rhineland is not in question. Even a critic of the French, such as Blanning (1983), admits the significant institutional reforms undertaken by the French in the Rhineland. Most significantly, in 1798 the seigneurial regime and the guilds were abolished (Blanning, 1983, pp. 137 and 155), and this paved the way to a relatively free labor market. This was a major reform and meant that master artisans could (and did) set up their shops when they wished to do so (Diefendorf 1980, p. 164). Equally important were the legal changes. For example, the French created a commercial court in Aachen in 1794, and followed with similar courts elsewhere in the Rhineland (Diefendorf, 1980, pp. 159-160), which were to play an important role in the creation of commercial and industrial businesses in the years to follow.

In Italy, several new Republics were established with French-style constitutions, parliaments (on a property-based franchise), and more efficient systems of administration. Extensive aristocratic privileges were abolished and the notion of equality before the law was introduced in earnest for the first time (see Doyle, 1989, Chapter 15, Grab, 2003, Chapter 10, Broers, 1997, 2005).

\subsection{Napoleon At the Helm}

After Napoleon's takeover, the French impact spread much wider throughout Europe. In Germany, where the direct control of the Revolutionary armies had been limited to the Rhineland, Napoleon constructed a string of satellite buffer states on France's northeastern border. There were several iterations, but the big break point followed the Peace of Lunéville (February 1801), with a massive reorganization of the territories that comprised the Holy Roman Empire (roughly Austria and Germany in their 1914 borders). Much of the astonishing variety of the Empire disappeared - literally hundreds of independent states, ecclesiastical territories and free imperial cities vanished and were consolidated into a cluster of larger kingdoms, principalities, and duchies; ultimately, their number shrank to fewer than 40 states (Grab, 2003, pp. 89-90). The main beneficiaries were the Grand Duchy of Baden and the kingdoms of Württenberg and Bavaria (all in the South of Germany). These and most other German states except Prussia were brought together in 1806 in the Rheinbund, known in English as the Confederation of the Rhine (see Schmitt, 1983).

At the same time, Napoleon proceeded to reorganize the territories in northwest Germany 
into satellite states under his control. The Duchy of Berg on the right bank of the Rhine was formed in March 1806 (it was supposed to be ruled by his infant nephew Louis Napoleon), the Kingdom of Westphalia (ruled by his brother Jérôme) in August 1807, and the Duchy of Frankfurt in February 1810 (it was planned that Napoleon's stepson, Eugene de Beauharnais, would inherit it). These were run by the French and persisted until the collapse following Napoleon's invasion of Russia. During this period Napoleon also took over parts of Northern Germany, including in December 1810 the annexation into France of Hamburg, Lübeck and Bremen (Hanseatic cities) and the plains of Lower Saxony, which would later comprise most of the Kingdom of Hanover.

Elsewhere the French maintained their control over the Low Countries, and in 1808 invaded Spain. In Italy Napoleon re-created the Cisalpine (subsequently Italian) and Ligurian Republics and created the satellite state of the Kingdom of Etruria comprising the larger part of Tuscany. By March 1802 the French commanded all of Italy except again the Papal States, Naples and Venice. Piedmont was annexed to France in early 1803, and in 1805 Napoleon turned the Italian Republic into the Kingdom of Italy (1805 to 1814) and the Ligurian Republic and Parma were made part of France. In 1806, the French again invaded southern Italy and Napoleon installed his brother Joseph as the King of Naples. The Papal States were invaded by the French in 1808, and most was annexed to France, forming the departments of Tiber and Trasimene. In 1808, Joseph was made King of Spain, and the Kingdom of Naples passed to Napoleon's brother-in-law, Joachim Murat.

\subsection{Napoleon's Reforms}

Although Napoleon was an Emperor seeking to solidify his control, ruthlessly when necessary, in France and throughout the French Empire, he nonetheless continued to implement the reforms initiated by the Revolutionary armies (see Grab, 2003, Connolly, 1965, and Woolf, 1991). As Grab (2003, p. xi) puts it: "Revolutionary France had initiated many of these changes and Napoleon exported them throughout Europe." Napoleon himself saw the imposition of the civil code (Code Napoléon) in the areas he controlled as his most important reform (Lyons, 1994, p. 94). In practice Napoleon's institutional legacy outside of France is complicated, especially since he was more inclined to compromise with local elites at some times, but in most places there was a genuine attempt to continue and deepen the reforms brought by the Revolution.

The motivation for the reforms seems to have been several. First, Napoleon had himself 
been deeply involved with the reforms of the Revolutionary period and seems to have shared the ideological commitment of the early reformers. Second, like them, he wished to build a series of buffer states around France. Finally, reforms such as abolishing elites, feudal privileges and introducing equality before the law undermined existing elites and made it easier for Napoleon to establish control over the areas rule he conquered. ${ }^{17}$

In Germany, Napoleon sustained the reforms already introduced into the Rhineland particularly introducing the Code Napoléon. Kisch emphasizes the economic importance of this (1989, p. 212): "When the many strands of commercial legislation were subsequently consolidated in the Code Napoléon, the Rhineland (on the left bank) was not only given a most up-to-date legal framework, but also a system of government in close harmony with the needs of a buoyantly industrializing society." The consequence of all of these changes was the transformation of the Rhineland from an oligarchy-dominated area to one open to new business and new entrants. Instead of the traditional oligarchy, in 1810 merchants/manufacturers comprised about half the members of Conseil General (municipal administrations) in leading Rhineland towns (Diefendorf, 1980, p. 115), and businesspeople were also well represented in the higher department-level Conseil General.

Reforms were also systematically introduced into the German satellite kingdoms. For example, Connelly (1965, p. 184) notes that in the constitution of Westphalia, which was issued at Fontainebleau on November 15, 1807,

“... the king's subjects were guaranteed equality before the law and religious liberty; serfdom and feudal rights were abolished; noble titles were affirmed, but were to command no special rights, privileges or offices. Taxes were to fall equally on all classes in all parts of the kingdom. Provision was made for a ministry, council of state, and a parliament of one hundred (seventy landowners, fifteen merchants and manufacturers, fifteen savants and distinguished citizens) ... Effective January 1, 1808, the Code Napoléon was to be the civil law. The judiciary was to be 'independent' but was appointed by the king, who could review his appointments every five years."

He later notes (p. 189) that "all vestiges of feudal law, together with seigneurial and church

\footnotetext{
${ }^{17}$ Prussia's desire to establish its own control seems to have been one of the reasons why it did not attempt to dismantle French reforms in the parts of Western Germany that it took over after 1815 (see Fisher, 1903, pp. 380-381).
} 
courts, disappeared in the first months of 1808 " and "All men were equal before the law and eligible for office." Although the political changes were not implemented (the parliament hardly met), the economic changes were profound and-in this case and in many otherslargely irreversible.

In the Netherlands, Belgium, and Switzerland, Napoleon consolidated the changes brought by the Revolution, with an emphasis on establishing (his) legal code and a downplaying of any move towards democracy. ${ }^{18}$

Napoleon's impact on Spain is controversial. Napoleon acquired nominal control over Spain quite late (1808) and from that time on he had considerable distractions in the form of almost continual major wars. The Code Napoléon was supposedly introduced, but it is unclear whether it was ever properly implemented. There was also considerable popular resistance, abetted by the British directly and through their base in Portugal, and by 1812 the French had lost effective control south of the Pyrenees.

In Italy, the picture is similar with the Code Napoléon being implemented mainly in the North, but also involving certain profound changes in the South.

\subsection{Persistence of the French Reforms}

After the final collapse of Napoleon in 1815 the institutional reforms implemented over the previous 25 years suffered various fates. In our econometric analysis of Germany we specifically code reforms throughout the 19th century so examine this issue empirically. As a first approximation, the reforms were most clearly persistent in places where the old elites did not return, for example, in the areas of Napoleonic Germany that were ceded to Prussia at the Congress of Vienna. For instance, Emsley (2003, pp. 62-63) notes:

"Yet on the left bank of the Rhine, in the departments annexed to France during the revolutionary decade, the Code became firmly entrenched. Indeed, it was so well entrenched that, after 1815, the Rhenish elite successfully preserved the Code and resisted attempts of their new Prussian masters to introduce the Prussian Allgemeines Landrecht." 19

\footnotetext{
${ }^{18}$ Napoleon also briefly invaded Portugal, but the French presence did not last long, partly due to British intervention. We therefore treat Portugal as part of the control group, along with Austria (where Napoleon also had military victories but never ruled directly).

${ }^{19}$ See Sperber (1989) and (1991) for details on the Rhinelanders tried (and succeeded for a long while) to hold onto the Code Napoléon and other progressive aspects of the French legacy.
} 
Emsley's argument is that the French reforms fundamentally changed the political status quo in such a way as the elites who benefitted from these institutions could sustain the. The presence of a new elite created by the reforms and determined to hang onto them is also central to the argument of Simms (2004, p. 39) who sums this up as:

\begin{abstract}
"In western and southern Germany there was no going back to the feudal status quo ante. The Prussian bureaucrats arriving in the newly acquired Rhine Province in 1815 found a population determined to hold onto the French law ... In southern Germany the old corporate representations had permanently given way to parliaments whose lower houses were largely elected on the basis of a property franchise; and by 1820 all southern German states had constitutions guaranteeing freedom of conscience and equality before the law ... The genie of the reform movement - freedom of movement, the standardization of taxation, the abolition of guilds - could not be put back in the bottle." 20
\end{abstract}

Although elsewhere, most notably in Hanover, there was much more of a return to the status quo, these examples highlight a plausible mechanism via which the reforms may have had enduring effects, even in places where the de jure aspects of French reforms were repealed after 1815 .

\title{
3 Data
}

In this section, we briefly describe the four types of data we use for our empirical analysis. In all cases, further details are contained in the Data Appendix.

\subsection{Country and Polity Level Outcome Variables}

We use two main data series to measure economic prosperity across countries and polities. ${ }^{21}$ Our first measure of prosperity is the urbanization rate of a country or a polity, measured as

\footnotetext{
${ }^{20}$ Note that the southern states mentioned here - Baden, Württemberg, and Bavaria - are not in our treatment group of invaded countries. To the extent that defensive modernization promoted economic growth, this will bias our result downwards, as we discuss later.

${ }^{21}$ Our units of observation are countries in their present-day borders where applicable, i.e., where political entities during the 19th century are roughly corresponding to today's borders. For the cases of Italy and Germany, two complicating factors occur: on the one hand, different regions of these countries experience different types of French 'treatment.' On the other hand, Italy and Germany are established as unitary states only towards the end of the 19th century. Therefore, we consider 8 distinct pre-unitary polities in Germany, and 12 such polities in Italy. For more details, refer to appendices 6 and 6 .
} 
the percent of the population living in cities with more than 5,000 inhabitants. We compute urbanization rates for 41 polities (21 present-day states, 8 German and 12 Italian pre-unitary states). Bairoch (1988, Chapter 1) and de Vries (1984, p. 164) argue that only areas with high agricultural productivity and a developed transportation network could support large urban populations. In addition, Acemoglu, Johnson and Robinson (2002) present evidence that both in the time-series and the cross-section there is a close association between urbanization and income per capita before as well as after industrialization. We take urbanization as the best available proxy for GDP per capita. Urbanization estimates from Bairoch (1988) and the city level population data from Bairoch, Batou and Chèvre (1988) are fairly reliable and build on the work of many economic historians. ${ }^{22}$ In addition, urbanization at this stage of European development is likely highly correlated with the growth of industrial activity based in cities.

We also use estimates of GDP per capita for national polities from Maddison (2003). The numbers before 1820 are in many cases educated guesses by Maddison. Furthermore, because these estimates are constructed for modern polities, such as Germany or Italy, they do not allow us to exploit the considerable variation within Germany and Italy. Maddison's estimates start in 1500, and are available for 1600, 1700, 1820, and then more frequently. We use the results with the GDP per capita estimates as a check on our urbanization rate results.

For Germany, we also collected data from the 19th century of the extent of railway networks and also the distribution of the population across different sectors of the economy (industry, commerce and agriculture). The sources for all these variables are listed in Appendix 6.

\subsection{Coding French Treatment}

We focus on three related measures of French treatment; these are summarized in Table 1 for all states in our datasets. The first records for each country the years of French occupation between the entire period 1792 and 1815. We consider years in which the French had direct control over these territories or installed republics and principalities directly dependent on French directives; we exclude years and months of pure military occupation, such as for example in the case of Prussia.

Our second measure is binary and reports as treated the areas invaded by the French

\footnotetext{
${ }^{22}$ The complete city level population dataset has information on all 2,200 European cities which had, at some time between 800 and 1800, 5,000 or more inhabitants. City level populations are added up and divided by total population, as garnered from McEvedy and Jones (1978), Lahmeyer (n.d.) or Maddison (2003). The Bairoch et al. dataset stops in 1850; therefore, we resort to official statistics of that period to estimate urbanization rates after that date. More details on the construction of urbanization figures are provided in Appendix 6 .
} 
revolutionary armies, thus the Netherlands, Belgium, Switzerland, most of northern and central Italy as well as the Rhineland. The third measure includes countries occupied by Napoleon. This adds Spain, Poland, most of Italy and the northwest of Germany. The untreated countries are all those in Europe which were not occupied and for which we have data. This includes Britain, Portugal, Austria, Scandinavia, Eastern Europe, and the southern and eastern German states Baden, Württemberg, Bavaria, Saxony, and Prussia. To the extent that some of these implemented modernizing reforms under pressure from France, through the implicit or explicit threat of invasion, this coding works against our hypothesis and biases our results downwards.

\subsection{Coding Institutional Reforms in Germany}

In the last part of our analysis, we also use an index of reforms in Germany, both to show the impact of the French occupation on institutional reforms and as the right-hand side variable in our instrumental-variables strategy. For our 8 polities in Germany we were also able to use historical sources to code the nature of some of the reforms that took place. The reforms we focus on are the enactment of written legal codes including the French civil code, the restructuring of agricultural relations, the abolition of guilds, and the emancipation of Jews. We interpret these reforms as a proxy or index for the overall set of institutional reforms, which also include changes in the nature of state administration or tax collection and the secularization of church lands. We are not able to construct measures of these reforms that are comparable across different areas of Germany (for example, the secularization of church lands was only relevant for Catholic territories). Table 2 shows the incidence of reforms in Germany.

Looking first at the top panel of Table 2, the first three columns report the treatment status for the 8 German polities for each of the three definitions of treatment. Column 1 , for example, shows that only what was to become the Prussian Rhine Province (the Rhineland) was treated during the Revolutionary period. In column 2, the Napoleonic treatment also includes Hanover and Westphalia (the latter also became part of Prussia after 1815). In column 3 we record the years of French control, which ranges for 19 years for the Rhineland to just 3 years for Hanover.

The next four columns record the date at which the different polities introduced the various reforms on which we focus. Appendix 6 describes in detail how we coded these reform dates and the sources we used. The first is the date at which a written legal code was introduced. The figures in this column indicate both the presence of a written civil code, and of a system 
of commercial law, represented either by the French code de commerce, or by the Prussian Allgemeines Landrecht (ALR). ${ }^{23}$ The Napoleonic civil code was introduced in 1805 in Frenchoccupied Rhineland and in 1808 in Westphalia. Other places such as Bavaria did not have such a code until 1900. Note that although Baden was never treated it introduced a version of the French civil code in 1810 . The next column examines agrarian reform, effectively abolition of serfdom or alternative feudal landholding arrangements, such as the Grundherrschaft, prevalent in south and west Germany (though in many cases peasants had to pay a compensation to their landlords). These reforms seem to have been relatively ineffective during the Napoleonic period itself even in the treated areas with the exception of the Rhineland. Column 6 of the table records when guilds were abolished. As this column reports, the abolition of guilds was one of the reforms most assiduously implemented by the French, but something that only happened elsewhere in Germany some 50 years later. Finally, column 7 presents data on the emancipation of the Jews. Though some historians have argued for the importance of this (Ferguson, 1998), the evidence does not suggest that these reforms were actually enacted very effectively. In most German states, full formal emancipation had to wait until the second half of the 19th century to be implemented.

In column 8 we construct a simple index of reforms at two exemplary dates, 1850 and 1900 for each polity by simply adding the number of years each particular reform had been in place and dividing by 4 . As an example, consider Hanover, which was taken over by the French for such a brief period that reforms were not implemented. By 1850 there had yet to be a written civil code; agrarian reform had been in place for 19 years; guilds had not been abolished; and Jews had not been emancipated. Therefore the value of the index for Hanover in 1850 is $19 / 4=4.75$. This index shows a clear distinction between parts of western Germany that were reformed by the French, those places which defensively modernized, like Prussia or Baden, and the rest of Germany. In 1850, for instance, the reform index was 33.5 for the Rhineland and 27.25 for Westphalia. The fact that it was 31.25 for Prussia and 26.25 for Baden shows how important the IV strategy is to avoid our results being biased by defensive modernization. Figure 1 plots the reform index over time showing the divergence between treated areas (Rhineland, Westphalia), defensive modernization areas (Prussia, Baden) and the rest of Germany.

The bottom panel of Table 2 reports some of the data in an intuitive form. We show

\footnotetext{
${ }^{23}$ The French implemented the civil code and the commercial code simultaneously and the ALR includes both types of codes, so we emphasized the timing of the introduction of both types of legal codes.
} 
the average date that different reforms were implemented, by treatment status. For instance, looking at the average date when guilds were abolished for polities which got the Napoleonic treatment, we see from column 6 that this was 1826, compared to 1853 for the control group. The last row of the table reports the correlation coefficient between the years of French control and the date when particular reforms were implemented. For example, in column 4 we see that the correlation between the date of introduction of a written civil code and years of French presence is -0.398 , so there is a sizable negative correlation-more years of French presence is correlated with an earlier introduction of a civil code. As will be clear from the table, the correlation with respect to the abolition of guilds is the largest.

\subsection{Other Data}

We also use a variety of other data as controls, in particular the proportion of the population of a polity who are Protestant, the latitude of the capital city of the polity, and initial values of the dependent variable.

\subsection{Descriptive Statistics}

Table 3A records some basic descriptive statistics of the complete cross-national dataset with the standard deviations in parentheses below the means. Panel A focuses on the urbanization dataset, while panel B examines the countries in the dataset with GDP per-capita.

The table consists of five columns. The first five rows describe urbanization rates in the five time periods considered; this evolution is also depicted in Figures 2A and 2B. One sees that the urbanization rate prior to the revolutionary period was larger in polities that were invaded by the Revolutionary armies compared to those that were not. The same is true with respect to the Napoleonic treatment. This suggests that invaded countries were richer in 1700 and also 1800. Nevertheless, until 1800-1850 the urbanization rates of the two groups do not display different evolutions (if anything, there is a slight convergence of the untreated group toward the treated group). So there seems to be little evidence of differential trends before the French Revolution. After 1850, there is a marked take-off of the treated states relative to the rest.

The next three rows of the table report summary statistics for the treatments status variables. Countries not invaded by French Revolutionary Armies still have 2.03 years of French presence on average (column 3), since they were later under Napoleonic control. The next row shows average latitude, which does not vary significantly between the treatment and control 
groups. The final row of this panel records the averages of our 'Protestant' variable, which shows that untreated polities are in general more likely to be Protestant.

Panel B of Table 3A shows some similar patterns. The sample is smaller now (since we do not have income variations within Germany or Italy) but we see that in 1700 income percapita was higher in treated than in untreated areas and remained so throughout the period of analysis. The picture with respect to latitude and Protestantism is also qualitatively similar.

In Table 3B we turn to descriptive statistics for the 8 German polities. In contrast to the whole sample we can see that, at least for the Napoleonic treatment,${ }^{24}$ there is little difference between the urbanization levels of treatment and control groups prior to 1789. This is also shown in Figures 3A and 3B. Indeed, in 1750 urbanization is slightly greater in the control group. Subsequently, however, urbanization grows more rapidly in the treatment group so that by 1900 it is a full 10 percentage points higher in areas occupied by Napoleon.

\section{Cross-Country Regression Evidence}

In this section we use ordinary least squares (OLS) regressions to investigate the cross-country reduced-form relationship between our three measures of treatment and the two basic outcome variables, urbanization rates and log GDP per capita. In all cases we have a panel dataset. For GDP per capita, the time periods are unevenly spread (e.g., from Maddison, 2003, we have income per capita for 1600, 1700, 1820, 1850, 1870, 1890 and 1900). For urbanization we have data for the periods $1700,1750,1800,1850$ and $1900 .^{25}$

Our basic reduced-form regression model is as follows:

$$
y_{j t}=d_{t}+\delta_{j}+\sum_{t \in \mathcal{T}^{\text {pre }}} \alpha_{t} \cdot D_{t} \cdot I_{j}+\sum_{t \in \mathcal{T}^{\text {post }}} \alpha_{t} \cdot D_{t} \cdot I_{j}+\mathbf{X}_{j t}^{\prime} \cdot \gamma+\varepsilon_{j t}
$$

where $y_{j t}$ is the outcome variable (urbanization or log GDP per capita) in country $j$ at time $t$, the $d_{t}$ 's denote a full set of time effects, the $\delta_{j}$ 's denote a full set of country (polity) fixed effects, $\mathbf{X}_{j t}$ is a vector of other covariates, which will be included in some of the robustness checks, and $\varepsilon_{j t}$ is a disturbance term. The key variable of interest for us is the treatment variable $I_{j}$, which is either a dummy denoting polities treated by the French Revolutionary armies/by Napoleon or the number of years of French occupation. The coefficients of interest

\footnotetext{
${ }^{24}$ Recall that for Germany the Revolutionary treatment affects only the Rhineland, which is why there are no standard deviations.

${ }^{25}$ The urbanization dataset is balanced except for Hanover and Bavaria in 1700, and the GDP per capita dataset is balanced except for Russia in 1850 and 1890.
} 
are thus $\sum_{t \in \mathcal{T}^{\text {pre }}} \alpha_{t}$ and $\sum_{t \in \mathcal{T}^{\text {post }}}$, where $\mathcal{T}^{\text {pre }}$ is the set of years before and $\mathcal{T}^{\text {post }}$ is the set of years after treatment, which together allow us to look at both pre-trends and post-French Revolution differential effects $\left(\sum_{t \in \mathcal{T}} \alpha_{t} \cdot D_{t} \cdot I_{j}\right.$ stands for a separate interaction for each $t$ in $\mathcal{T}$ ). Under our hypothesis that French occupation was 'econometrically exogenous', we expect the coefficients $\left\{\alpha_{t}\right\}_{t \in \mathcal{T} \text { pre }}$ not to be significantly different from zero, and under our hypothesis that the French reforms were beneficial for long-run economic growth, we expect $\left\{\alpha_{t}\right\}_{t \in \mathcal{T} \text { post }}$ to be positive.

Throughout the paper, all standard errors are robust, clustered at the country/polity level to allow for an arbitrary variance-covariance matrix capturing potential serial correlation in the residual error term (see Wooldridge, 2002, Chapter 7). ${ }^{26}$

\subsection{Main Results: Urbanization}

We start in Table 4 with our preferred measure of prosperity in the 19th century, urbanization rates, as the dependent variable, $y_{j t}$. The first column uses years of French occupation as the treatment, while the second uses invaded by the French during the Revolutionary period as the treatment. Column 3 uses invasion during the Napoleonic period as the treatment. Finally, column 4 uses years of French presence but weights the polities by their population in 1700 .

The set $\mathcal{T}^{\text {post }}$ includes the treatment years 1850 and 1900, $\mathcal{T}^{\text {pre }}$ comprises 1750 and 1800, with 1700 as the omitted year. In column 1 we see that $\hat{\alpha}_{1850}=-0.236$ with a standard error of 0.154 , so that by 1850 there was a negative, though relatively small and statistically insignificant effect of years of French presence on the growth of urbanization. By 1900, however, a significant positive effect occurs. Indeed, $\hat{\alpha}_{1900}=0.899$ (standard error $=0.382$ ). Importantly, there is no evidence of a pre-trend favoring the treated areas. The coefficients $\hat{\alpha}_{1750}$ and $\hat{\alpha}_{1800}$ are in fact negative, but statistically insignificant. ${ }^{27}$

The patterns in columns 2 and 3, which use dummies for control by the French Revolu-

\footnotetext{
${ }^{26}$ The Huber-White standard errors turn out to be smaller than the standard errors clustered at the country/polity level in almost all cases. So our use of the fully robust variance-covariance matrix is conservative except for the possibility that asymptotic approximations may not be valid because of the limited numbers of clusters. As a remedy for this last possibility, we also discuss how using the alternative wild bootstrap procedure suggested by Cameron, Gelbach and Miller (2008) affects the significance levels of our estimates.

${ }^{27}$ One concern, already mentioned in footnote 26 , is that the number of clusters in Table 4 is relatively small (41 polities). As a potential check, we also computed the significance levels for our parameter estimates using the wild bootstrap procedure (based on the t-statistics with the null hypothesis imposed) as suggested by Cameron, Gelbach and Miller (2008). We computed the significance levels using 1000 replications. This procedure has little effect on the significance levels of the results in Table 4. For example, in column 1 the p-value for $\hat{\alpha}_{1900}$ increases slightly from 0.024 to 0.034 , and the p-value of the F-test of joint significance of the coefficients $\alpha_{1850}$ and $\alpha_{1900}$ changes from 0.001 to 0.008 . Similar results apply to the other estimates in Table 4 .
} 
tionary armies and by Napoleon as the measure of French treatment, and in column 4, which uses weighted regressions (using population in 1750 as weights), are similar to that in column 1. We continue to find a negative and insignificant effect of being occupied by the French in 1850, and a positive and significant effect in 1900. The estimates of the coefficient $\alpha_{1900}$ are not statistically significant in columns 2 and 4 . Nevertheless, in all cases, the F-test shows that the 1850 and 1900 interactions are jointly significant, reflecting the fact that the differences between the 1850 and 1900 coefficients are statistically significant in all specifications.

However, the pre-1800 coefficients are now larger, and in column 2 and 4, they are statistically significant. This raises the possibility of potential mean reversion, which may confound our estimates. To deal with this concern, we report results from models that explicitly allow for mean reversion in the next subsection.

The quantitative effects implied by these estimates are economically large but reasonable. For example, the estimate of $\alpha_{1900}$ in column 1 implies that by 1900 countries that experienced 10 years of French control had urbanization rates almost 9 percentage points higher. This is a large effect relative to mean urbanization in 1900 which was $41.2 \%$ for the entire sample, suggesting an increase of close to $22 \%$ (or half a standard deviation) in the urbanization rate. The effects estimated for $\alpha_{1900}$ in columns 2 and 3 using treatment dummies are also quantitatively very similar.

Overall, these results show no evidence of a negative effect of French occupation. On the contrary, they suggest that polities invaded and reformed by the French experienced more rapid urbanization and economic growth after 1850 . We find it reasonable that the positive effects of the French Revolution exhibit themselves after 1850, since, as discussed in Section 2, the main role of the French reforms was to remove the barriers against industrialization and industrial technology and such practices did not spread in continental Europe until the second half of the 19th century.

\subsection{Robustness}

Tables 5 and 6 investigate the robustness of our initial results. In Table 5 we re-estimate the basic model from column 1 of Table 4, focusing on years of French presence as our measure of French treatment, and add some simple covariates. Column 1 reproduces column 1 of Table 4. In column 2 we add, as covariate vector $\mathbf{X}_{j t}$, latitude interacted with a full set of time dummies to allow for a time varying impact of geography (i.e., $\sum_{t} \eta_{t} \cdot D_{t} \cdot$ latitude $_{j}$ ). Table 5 , 
column 2 shows that though the interactions between latitude and time effects are statistically significant, controlling for these interactions has no effect on the estimated effects of French treatment. ${ }^{28}$

In column 3 , we include a full set of interactions between initial urbanization $y_{j 1750}$ and the full set of year dummies (i.e., $\sum_{t} \eta_{t} \cdot D_{t} \cdot y_{j 1750}$, where 1750 is the first date with complete urbanization figures for all polities). This is a flexible (and demanding) way of controlling for any pre-existing trends and mean reversion. The negative and sometimes statistically significant estimates before 1800 shown in Table 4 raise the possibility that there might be significant mean reversion in economic growth during this era, potentially confounding our estimation strategy. Nevertheless, this flexible specification has little effect on our estimates. For example, $\hat{\alpha}_{1900}$ is now 0.85 (standard error $=0.396$ ) and the interactions between initial urbanization and the year dummies are also statistically insignificant.

In column 4, we include a full set of interactions between year dummies and our 'Protestant' variable. Several influential social scientists have argued for the importance of the Protestant work ethic in causing or at least facilitating industrialization (e.g., Weber, 1905, Landes, 1998). Although there is some evidence of differential growth of Protestant countries (the set of interactions between Protestantism and the time dummies is significant at the $5 \%$ level), the inclusion of this set of covariates only strengthens the differential growth effect of French treatment. Column 5 finally includes all of these interactions jointly. Our estimates are again largely unaffected.

In Table 6 we conduct a variety of other robustness checks again restricting attention to years of French presence as our measure of French treatment. In column 1 for ease of comparison we again reproduce the regression from column 1 of Table 4 . In the second column we drop the United Kingdom, since the British were the industrial leader at the time and their industrialization trajectory may have been unaffected by the French Revolution. This again has little impact on our results; $\hat{\alpha}_{1900}$ is now estimated to be slightly larger and highly significant. Eastern Europe, where serfdom was more widespread, may also be a poor control for more western areas. Motivated by this reasoning, in column 3 we drop both the United Kingdom and Eastern Europe. The basic pattern remains unchanged, though with a slightly smaller coefficient $\hat{\alpha}_{1900}$. In column 4 , we drop Germany and Italy, as a preparation for the results

\footnotetext{
${ }^{28}$ As with the results in Table 4, those in Tables 5 and 6 are robust to using the wild bootstrap procedure to compute p-values, and our estimates remain significant at conventional levels. For example, using the same procedure as in footnote 27 , the p-value for $\hat{\alpha}_{1900}$ in column 2 changes from 0.025 to 0.028 , and the p-value of the F-test of joint significance of the coefficients $\alpha_{1850}$ and $\alpha_{1900}$ increases from 0.001 to 0.014 .
} 
using Maddison's data, where we cannot distinguish across German and Italian sub-national polities. In this case, the qualitative pattern of the results is similar, but $\hat{\alpha}_{1900}$ is much smaller and statistically insignificant. This already constitutes a warning about the interpretation of the results using Maddison's GDP estimates, where we will lose all of the within Germany and Italy variation.

The remaining columns of Table 6 , allow for mean reversion using the alternative strategy of explicitly introducing the lagged dependent variable on the right-hand side. To ensure consistency, these models are estimated using the Generalized Method of Moments (GMM) strategy suggested by Arellano and Bond (1991). The results are generally similar to the OLS estimates without the lagged dependent variable and the lagged dependent variable itself is insignificant.

Also noteworthy is that in all of these specifications, we do not find evidence of pre-trends favoring areas subsequently occupied by the French. We find this reassuring for our overall empirical strategy.

\subsection{Results with GDP Per Capita}

Table 7 reports estimates of equation (1) using GDP per capita as the dependent variable. The baseline specification, reported in columns 1, 2, and 3, excludes Italy and Germany, since these countries comprise both treated and untreated sub-national polities. In addition, the set $\mathcal{T}^{\text {pre }}$ (for the pre-trend specification tests) now includes 1700 and 1820 (even though there may already be some effect in 1820), while $\mathcal{T}^{\text {post }}$ includes 1850, 1870, 1890 and 1900. With all three measures of French treatment, there is no evidence of significant effects before 1850. The coefficients for 1850 and thereafter are all positive and individually statistically significant in columns 1 and 2. In column 3, where we use the dummy variable for control by Napoleon, the effects are not statistically significant. ${ }^{29}$ The quantitative magnitudes of the estimates are also similar to the results with urbanization rates. For example, the estimate of $\hat{\alpha}_{1900}$ in column 2, 0.359, implies that by 1900 countries that were occupied by the French Revolutionary armies would have reached about $36 \%$ higher per capita income relative to unoccupied countries.

The remainder of Table 7 focuses on the measure of years of French presence and reports specifications that also include Italy and Germany (column 4), excludes the United Kingdom

\footnotetext{
${ }^{29}$ However, in contrast to the results in Tables 4-6, the statistical significance of the estimates in this table is not robust to using bootstrapped p-values. Typically, the p-value of the F-statistic resulting from a test of joint significance of all post-1820 coefficients increases to approximately 0.5 and is thus highly insignificant. This suggests that the results using GDP per capita should be interpreted with caution.
} 
(column 5), also excludes Eastern Europe (column 6) and includes a full set of latitude, Protestant an initial GDP time interactions (column 7). The overall pattern is similar. None of the specifications show statistically significant differential effects before 1850, and all specifications show positive effects after (and including) 1850. While individual coefficients are insignificant in many specifications, the F- tests for the joint significance of all post-1820 interactions (1850 onwards) in all cases indicate that there is significantly faster growth in countries occupied by the French after 1850.

In sum, results using Maddison's GDP estimates also show no evidence that the French evolution have negative economic consequences. In fact, the estimates show a positive effect of the French revolution, particularly after 1850 (though this is less robust than the results with urbanization). As we mentioned in the Introduction, however, using this GDP data entails discarding a considerable amount of variation in treatment, which comes from the within Italy and within Germany experiences. This is the reason why we have emphasized the urbanization data as our main dependent variable.

\section{Within-German Evidence}

The results so far indicate that countries where the French Revolution imposed radical institutional reforms, such as the abolition of feudal land relations and the power of the guilds, experienced faster growth in the second half of the 19th century, particularly after the industrialization process got underway in earnest in continental Europe. We now look at the variation within Germany, which is useful for several reasons. First, it will enable us to focus on a sample of polities that were more homogeneous than the whole set of European countries at the turn of the 19th century. Second, the greater availability of data will allow us to pinpoint more precisely when in the second part of the 19th century the divergence between occupied and unoccupied areas may have started. Finally and most importantly, we will be able to use detailed data on institutional reforms and other outcome variables to further investigate the implications of the reforms imposed by the French Revolution.

\subsection{Reduced-Form Results}

We first examine reduced-form models similar to those estimated in Tables 4-6, but for the 8 German polities for which we have urbanization data. Our estimating equation is identical to (1), with $y_{j t}$ again corresponding to the urbanization rate, but now defined for to sub-national 
German polities. The rest of the variables are defined similarly to those in equation (1): the $d_{t}$ 's denote a full set of time effects, the $\delta_{j}$ 's denote a full set of city effects, $\mathbf{X}_{j t}$ is a vector of other covariates, and $\varepsilon_{j t}$ is the error term. The dummy $I_{j}$ is again the treatment status defined in the same three ways.

Our baseline sample now consists of the years 1700, 1750, 1800, 1850, 1875, 1880, 1885, 1890, 1895, 1900, 1905 and 1910; we are thus able to take advantage of the richer information we have about urbanization within Germany as compared to the rest of Europe. We take the set $\mathcal{T}^{\text {post }}$ to consist of the years between 1850 and 1910, while the set $\mathcal{T}^{\text {pre }}$ (for the pre-trend specification check) consists of 1750 and 1800. 1700 is the omitted category.

The estimates from the baseline models are reported in Table 8. The first column uses years of French presence as the treatment. There is again no evidence of differential growth before 1850: $\hat{\alpha}_{1750}$ and $\hat{\alpha}_{1800}$ are small and statistically significant. In contrast, $\hat{\alpha}_{1850}$ is positive, though insignificant. By 1875 there is a statistically significant effect of treatment with $\hat{\alpha}_{1875}$ equal to 0.71 (standard error $=0.20$ ). In addition, the differential growth continues thereafter so that by 1910 we have $\hat{\alpha}_{1910}=1.07$ (standard error $=0.37$ ). This indicates that the differential effects of French treatment start relatively early in the second part of the 19th century (certainly well before 1900). Quantitative magnitudes are comparable as well, but somewhat larger than those from the cross-country estimates. For example, the coefficient of $\hat{\alpha}_{1900}=0.99$ indicates that a polity that experienced 10 years of French control, on average, achieved about 10 percentage points higher urbanization relative to unoccupied areas. ${ }^{30}$

In column 2 we use invasion of Revolutionary armies as our measure of French treatment. Recall that in the German context, this is simply testing for differential growth of urbanization in the Rhineland versus the rest of Germany. The pattern here is similar to that in column 1, with the estimated effect becoming significant in 1875 , the size of the coefficient increasing over time and the significance level remaining high. In column 3 we use the dummy variable for occupation by Napoleon; the results are again broadly similar.

In column 4, we use the years of French control measure and exclude the part of Prussia that was not incorporated into Napoleon's satellite kingdom, which lies for the most part east of the Elbe. This is a useful check since the eastern German areas with stronger feudal labor relations may be less comparable to, and thus are worse control, for polities occupied by the

\footnotetext{
${ }^{30}$ As in Table 7 (and in contrast to Tables 4-6), these results are not robust to using wild bootstrapped significance levels. For example, in column 1, the p-value for the test of joint significance of all post-1800 coefficients increases from 0.000 to 0.360 .
} 
French. In the event, the results in column 4 are very similar to those in column 1 and indicate that our findings are not given by a comparison of the west and east of the Elbe. ${ }^{31}$

Columns 5-7 focus on the years of French control measure and include interactions of Protestant, latitude and initial urbanization with linear time trends, while column 8 weights the data by population in 1700. The results are similar to those in column 1. Finally, column 9 reports results from a specification including a lagged dependent variable. For this specification, we only include the years $1700,1750,1800,1850$, 1900, to obtain a panel dataset with evenly spaced time intervals. The estimates are again similar to those in column 1.

Overall, the evidence in Table 8 is consistent with that presented in the previous sections. In fact, the effects of French treatment are somewhat more precisely estimated, and because we have more frequent observations, we can see the effects occur as early as 1875 . We conclude, in line with our results from the previous section, that there is no evidence of a negative economic impact of the French Revolution; on the contrary, there is considerable evidence indicating that areas occupied by the French grew considerably faster in the second half of the 19th century.

\subsection{Instrumental-Variables Models in Germany}

One advantage of our within Germany analysis is that we can verify the impact of French treatment on institutional reforms and then also estimate models where all of the effects of French occupation are assumed to work through institutions. In particular, we posit the following simple relationship between our index of institutional reform and French occupation:

$$
R_{j t}=d_{t}+\delta_{j}+\psi \cdot t \cdot T_{t>1800} \cdot I_{j}+\eta_{j t}
$$

where $R_{j t}$ is the value of the reform index for polity $j$ in Germany at time $t$, which was introduced in the context of Table 1 above. $d_{t}$ and $\delta_{j}$ are time effects and polity fixed effects and as usual $I_{j}$ is our treatment variable, which in this section we take to be years of French presence. $\eta_{j t}$ is a disturbance term. The variable $T_{t>1800}$ is a dummy for post-1800 dates, so that $t \cdot T_{t>1800}$ is a linear time trend that turns on after 1800 (and is equal to 0 before then). ${ }^{32}$

\footnotetext{
${ }^{31}$ The results including the areas East of the Elbe are useful, on the other hand, because they provide evidence against a related but different hypothesis that part of the effects of French occupation within Germany are partly (or largely) due to defensive modernization efforts of Prussia (itself triggered by the French Revolution). After the Congress of Vienna in 1815, Prussia took over large parts of Napoleonic Western Germany including the Rhineland and Westphalia. As noted in footnote 17, this is part of the explanation for why institutional reforms were not reversed in Germany after Napoleon's fall. Nevertheless, our interpretation is that the within-Germany results are unlikely to be due to such a Prussian effect. First, the general pattern is similar for the whole of Europe. Second, in Germany much of Prussia is itself in the control group.

${ }^{32}$ To simplify the interpretation of coefficients, time $t$ is divided by 1000 .
} 
We start with this simpler form in (2), because in the second stage we are interested in the main effect of institutional reforms and thus using a full set of time interactions as instruments might exaggerate the strength of our first-stage relationship. We return to a specification in which the full set of time interactions are used in the first stage in columns 3 and 4 .

The second-stage equation is

$$
y_{j t}=d_{t}+\delta_{j}+\phi \cdot R_{j t}+v_{j t}
$$

where $y_{j t}$ is urbanization, $d_{t}$ and $\delta_{j}$ are time effects and polity fixed effects.

Table 9 shows the results of estimating (3) using OLS and two-stage least squares. Column 1 is for the entire Germany using years of French presence as the measure of French treatment. Panel A shows estimates (3) using OLS for comparison. The reforms index has a positive and statistically significant effect on urbanization with an estimated coefficient of $\hat{\phi}=0.368$ (standard error $=0.13$ ).

Panel B depicts estimates of equation (2). It shows a strong first stage with the coefficient on the interaction between the post dummy and years of French presence being $\hat{\psi}=0.711$ (standard error $=0.25$ ). The strong first-stage relationship indicates that even though there were reforms in German areas not occupied by the French (most likely due to defensive modernization as in Baden and in Prussia), occupation by the French was a significant determinant of reform.

Panel $\mathrm{C}$ reports the second stage. These results show that the impact of reforms on urbanization is also highly significant, now with a larger coefficient $\hat{\phi}=0.658$ (standard error $=0.21$ ). The greater magnitude of this coefficient is not surprising in view of the fact that the OLS coefficient is likely to be subject to considerable attenuation, both because the extent of reform is measured with error and also because, conceptually, our reforms are only proxies for a broader range of institutional reforms undertaken during this era. ${ }^{33}$ Column 2 repeats these regressions excluding the East of the Elbe and shows very similar results to column 1.

Columns 3 and 4 reestimate the same models as in columns 1 and 2, but instead of a linear interaction of time with years of French presence in the first stage, they include a full set of interactions between post-1800 dummies and years of French presence (as in equation (1)). We do not show the corresponding first stages in Panel B to save space. This exercise is useful for two reasons. First, the very similar coefficients in columns 3 and 4 show that

\footnotetext{
${ }^{33}$ The results in this table are weakened by the use of the wild bootstrap-t method, with the level of significance for $\hat{\phi}$ typically increasing to around or just above $10 \%$.
} 
using the linear time interaction in (2) is not important for our results. Second, because with this specification we have more instruments than endogenous regressors, we can perform an overidentification test of the validity of the instruments. Economically, this amounts to testing whether we can reject the hypothesis that all of the effects of the post-1800 time interactions with French occupation work through the reforms index. To perform the overidentification test, we use the Huber-White variance-covariance matrix without clustering, since this corresponds to smaller standard errors and thus stacks the cards against our hypothesis. The results show that the overidentification tests are very far from rejecting the above-mentioned hypothesis. This gives some support to our interpretation that French occupation impacted urbanization and economic growth in German polities in the second half of the 19th century mainly through the reforms that the French imposed.

Columns 5-8 include interactions between Protestant, latitude and initial organization and linear time trends (these models again only include a linear interaction of time with years of French presence in the first stage, as in (2)). These controls have little effect on the results. Finally, column 8 reports weighted regressions, again showing a very similar pattern to the results in column 1 .

Overall the results in this section are consistent with our interpretation that occupation by the French induced significant institutional reforms and these reforms paved the way for more rapid economic growth particularly in the second half of the 19th century.

\subsection{Other German Outcome Variables}

Our focus so far on urbanization rates and GDP per-capita was driven by our desire to check for pre-trends - both of these variables allowed us to see whether there were differential changes before the French Revolution. The lack of such pre-trends so far motivates us to look at other proxies for economic growth and industrialization in the 19th century. More specifically, we focus on the length of railway tracks in the area and the sectoral composition of employment, which are available for German administrative units in the 19th century, but not before.

Given the absence of pre-French Revolution data, we adopt a simpler strategy in this subsection. We report a series of cross-sectional regressions of the form:

$$
y_{j t}=d_{t}+\alpha_{t} \cdot I_{j}+\varepsilon_{j t}
$$

for each $t$. Here $y_{j t}$ is again the outcome variable (railways or sectoral shares) in district $j$ at time $t, d_{t}$ now denotes a year-specific constant, $I_{j}$ again represents years of French presence 
in district $j, \varepsilon_{j t}$ is a disturbance term, and $\alpha_{t}$ 's are the coefficients of interest. In particular, changes in $\alpha_{t}$ 's can be interpreted as differential growth related to French treatment.

Data on railways construction are available at the level of districts (Regierungsbezirke). In our dataset, districts have an average size of 12,000 square $\mathrm{km}$ and a population of 1.15 million inhabitants. Data until 1874 are available only for Prussia, from 1880 onwards for the entirety of the German Empire. There are 35 districts in Prussia, 38 in the rest of Germany. We are thus able to look at railways in the years 1859, 1864, 1869, 1874, 1880, 1885, 1890, 1895.

Table 10 shows the results of estimating equation (4) with the left-hand side variable as log kilometers of railways in district $j$. The regressions for 1859, 1864, 1869, and 1874, show no significant differences in railway tracks by years of French presence both in the entire Germany and in the West of the Elbe. However, by 1880 (after the non-Prussian districts are added to the dataset) we find significantly more railway tracks in areas occupied by the French. These differences are confirmed in subsequent periods, particularly when attention is confined to the West of the Elbe.

Table 11 turns to the sectoral shares of employment. Economic progress in the 19th century was associated with a move out of agricultural activities and into the industrial and manufacturing sectors. We exploit variation across districts in sectoral shares of employment, based on data assembled by Frank (1994) for four points in time: 1849, 1882, 1895, and 1907. The results in Table 11 show that by 1849 there was already less agriculture and greater industry and manufacturing employment in areas occupied by the French, though these differences are not statistically significant. They become larger and statistically significant by 1882 and remain so until 1908. This evidence therefore also suggests that there was more rapid industrialization in areas that underwent more significant reforms because of French occupation and invasion.

\section{Conclusion}

The French Revolution of 1789 had a momentous impact on France and its neighboring countries. The Revolution violently toppled the established regime and started a complex process, involving both the infamous French Terror and also radical institutional changes, including the abolition of the remnants of feudalism in agriculture, the reduction of the power of the nobility and the clergy, the abolition of guilds and internal tariffs, and the declaration of equality before the law for all citizens.

More importantly for the focus of this paper, the French Revolutionary armies, and later 
Napoleon, invaded and controlled Belgium, the Netherlands, Italy, Switzerland, parts of Germany. In all of these places, the Revolution undertook essentially the same radical political, legal, and economic reforms as in France. However, invasion by the French Revolutionary armies (and later by Napoleon) also came with chaos and the exploitation of the occupied territories.

Despite the very large literature on the causes and consequences of the French Revolution, there has been little investigation into the long-run implications of the institutional changes brought about by the French Revolution. This paper is an attempt in this direction and it investigates the implications of the radical institutional reforms imposed by the French armies on neighboring countries as a quasi-natural experiment.

The evidence suggests that areas that underwent the institutional reforms of the French Revolution experienced more rapid urbanization, especially after 1850. This pattern is fairly robust when we look at cross-country data on urbanization and if anything stronger when we focus on within-Germany variation. Even though it is much less satisfactory for examining these issues, when we use Maddison's data on GDP the overall pattern is similar, though the results are somewhat weaker.

These findings are interesting not only as a historical appraisal of the economic impacts of the Revolution but more importantly because of their implications for the role of institutions in economic development and for the debate about sources of institutional change. The historical experience we have studied is a clear example of a large-scale and radical institutional change. In this light, our findings support recent empirical work emphasizing the centrality of institutional differences for comparative economic development. More importantly, the results are inconsistent with influential theses in social sciences emphasizing the potential negative effects of the French Revolution because it imposed potentially 'inappropriate,' 'designed' and 'French' institutions in a 'Big Bang' style - all of these often argued to be inimical to economic progress. On the contrary, the evidence supports our hypothesis that the institutions of the ancien régime impeded prosperity, and that the radical institutional reforms removed these barriers and paved the way for industrialization and economic growth. Naturally, all of these findings have to be interpreted with caution, both because our analysis was limited to the available historical data and results from one historical episode cannot always be extrapolated to other eras. Nevertheless, it is noteworthy that our findings do suggest that radical institutional reforms can have long-run beneficial consequences, at least in certain historical contexts. 


\section{References}

Acemoglu, Daron (2008) "Oligarchic vs. Democratic Societies," Journal of the European Economic Association, 6, 1-44.

Acemoglu, Daron, Davide Cantoni, Simon Johnson and James A. Robinson (2009) "From Ancien Régime to Capitalism: The French Revolution as a Natural Experiment," forthcoming in Jared Diamond and James A. Robinson eds. Natural Experiments in History, to be published by Harvard University Press.

Acemoglu, Daron and Simon Johnson (2005) "Unbundling Institutions," Journal of Political Economy 113, 949-995.

Acemoglu, Daron, Simon Johnson and James A. Robinson (2001) "The Colonial Origins of Comparative Development: An Empirical Investigation," American Economic Review, December, 91, 5, 1369-1401.

Acemoglu, Daron, Simon Johnson and James A. Robinson (2002) "Reversal of Fortune: Geography and Institutions in the Making of the Modern World Income Distribution," Quarterly Journal of Economics, 118, 1231-1294.

Acemoglu, Daron and James A. Robinson (2008) "Persistence of Power, Elites, and Institutions," American Economic Review, 98(1), 267-293.

Arellano, Manuel and Stephen R. Bond (1991) "Some Specification tests for Panel Data: Monte Carlo Evidence and an Application to Employment Equations," Review of Economic Studies, 58, 277-298.

Bairoch, Paul (1988) Cities and Economic Development: From the Dawn of History to the Present, University of Chicago Press.

Bairoch, Paul, Jean Batou and Pierre Chèvre (1988) La Population des villes Europenees de 800 a 1850: Banque de Données et Analyse Sommaire des Résultats, Centre d'histoire économique Internationale de l'Uni. de Genève, Geneva; Libraire Droz.

Berkowitz, Daniel, Katharina Pistor and Jean-Francois Richard (2003a) "The Transplant Effect," American Journal of Comparative Law, 51, 163-204.

Berkowitz, Daniel, Katharina Pistor and Jean-Francois Richard (2003b) "Economic Development, Legality and the Transplant Effect," European Economic Review, 47, 165-195.

Blanning, Timothy C.W. (1983) The French Revolution in Germany: Occupation and Resistance in the Rhineland, 1792-1802, New York; Oxford University Press. 
Blanning, Timothy C.W. (1986) The Origins of the French Revolutionary Wars, London; Longman.

Blanning, Timothy C.W. (1996) The French Revolutionary Wars, 1787-1802, New York; St. Martin's Press.

Blum, Jerome (1978) The end of the old order in rural Europe, Princeton; Princeton University Press.

Braudel, Fernand (1992) Civilization and Capitalism 15th-18th Century; Volume III The Perspective of the World, Berkeley; University of California Press.

Broers, Michael (1997) Napoleonic Imperialism and the Savoyard Monarchy, 1773-1821: State Building in Piedmont, Lewiston; Edwin Mellen Press.

Broers, Michael (2005) The Napoleonic Empire in Italy, 1796-1814: Cultural Imperialism in a European Context? New York; Palgrave Macmillan.

Burke, Edmund (1790/1969) Reflections on the Revolution in France, Baltimore; Penguin Books.

Buyst, Erik and Joel Mokyr (1990) "Dutch Manufacturing and Trade during the French Period (1975-1814) in a Long Term Perspective," in Erik Aerts and François Crouzet eds. Economic Effects of the French Revolutionary Wars, Leuven; Leuven University Press.

Cameron, A. Colin, Jonah B. Gelbach and Douglas L. Miller (2008) "BootstrapBased Improvements for Inference with Clustered Errors," Review of Economics and Statistics, 90, 414-427.

Cameron, Rondo (1993) A Concise Economic History of the World, Second Edition, New York; Oxford University Press.

Cipolla, Carlo M. (1970) "The Economic Decline of Italy," in Carlo M. Cipolla ed. The Economic Decline of Empires, New York; Barnes and Noble.

Connelly, Owen (1965) Napoleon's Satellite Kingdoms, New York; Free Press.

Crouzet, François (2001) A History of the European Economy, 1000-2000, Charlottesville; University of Virginia Press.

Davis, John (1991) "The Napoleonic Era in Southern Italy: An Ambiguous Legacy?" Proceedings of the British Academy, 80, Lectures and Memoirs 134.

Davis, John (2003) "The Many Faces of Modernity: French Rule in Southern Italy, 1806-1815," in Michael Rowe ed. Collaboration and Resistance in Napoleonic Europe, New York; Palgrave Macmillan. 
Demsetz, Harold (1967) "Towards a Theory of Property Rights," American Economic Review, 57, 347-359.

de Vries, Jan (1984) European Urbanization, 1500-1800, Harvard University Press.

Djankov, Simeon, Edward L. Glaeser, Rafael La Porta, Florencio Lopez-deSilanes and Andrei Shleifer (2003) "The New Comparative Economics," Journal of Comparative Economics, 31, 595-619.

Diefendorf, Jeffry (1980) Businessmen and Politics in the Rhineland, 1789-1834, Princeton; Princeton University Press.

Doyle, William (1989) The Oxford History of the French Revolution, Oxford; Oxford University Press.

Ellis, Geoffrey (2003) The Napoleonic Empire, New York; Palgrave Macmillan.

Emsley, Clive (2003) Napoleon: Conquest, Reform and Reorganization, New York; Pearson/Longman.

Engerman, Stanley L. and Kenneth L. Sokoloff (1997) "Factor Endowments, Institutions, and Differential Paths of Growth Among New World Economies: A View from Economic Historians of the United States," in Stephen Haber, ed., How Latin America Fell Behind, Stanford; Stanford University Press.

Esdaile, Charles J. (1995) The Wars of Napoleon, New York; Longman.

Esdaile, Charles J. (2001) The French Wars, 1792-1815, New York; Routledge.

Ferguson, Niall (1998) The world's banker: the history of the house of Rothschild, London; Weidenfeld \& Nicolson.

Fisher, Herbert A. L. (1903) Studies in Napoleonic statesmanship: Germany, Oxford; Clarendon Press.

Frank, Harald (1994) Regionale Entwicklungsdisparitäten im deutschen Industrialisierungsprozess 1849-1939: Eine empirisch-analytische Untersuchung, Münster; Lit.

Gates, David (1997) The Napoleonic Wars, 1803-1815, New York; St. Martin's Press.

Grab, Alexander (2003) Napoleon and the Transformation of Europe, New York; Palgrave Macmillan.

Gregory, Desmond (2001) Napoleon's Italy, London; Associate University Press.

Hayek, Friedrich (1960) The Constitution of Liberty, Chicago; University Of Chicago Press.

Kisch, Herbert (1962) "The Impact of the French Revolution on the Lower Rhine textile 
districts - Some Comments on Economic Development and Social Change," Economic History Review, New Series, 15, 304-327.

Kisch, Herbert (1989) From Domestic Manufacture to Industrial Revolution: The case of the Rhineland Textile Districts, New York; Oxford University Press.

Lahmeyer, Jan (n.d.) Population statistics: historical demography of all countries, their divisions and towns, http://www.populstat.info/

Landes, David S. (1969) The Unbound Prometheus, Cambridge University Press.

Landes, David S. (1998) The Wealth and Poverty of Nations: Why Some are So Rich and Some So Poor, New York; W.W. Norton.

La Porta, Rafael, Florencio Lopez-de-Silanes, Andrei Shleifer, and Robert W. Vishny (1998) "Law and Finance," Journal of Political Economy, 106, 1113-1155.

Lenger, Friedrich (2004) "Economy and Society," in Jonathan Sperber ed. The Shorter Oxford History of Germany: Germany 1800-1870, New York; Oxford University Press.

Lyons, Martyn (1994) Napoleon Bonaparte and the Legacy of the French Revolution, New York; St. Martin's Press.

Maddison, Angus (2003) The World Economy: Historical Statistics, OECD.

McEvedy, Colin and Jones, Richard (1978) Atlas of world population history, Harmondsworth and New York; Penguin.

Mitchell, Brian R. (1981) European Historical Statistics, 1750-1975, Facts on File, New York.

Mokyr, Joel (1990) The Lever of Riches, New York; Oxford University Press.

North, Douglass C. and Robert P. Thomas (1973) The Rise of the Western World: A New Economic History, Cambridge; Cambridge University Press.

Ogilvie, Sheilagh (2004) "Guilds, efficiency, and social capital: Evidence from German protoindustry," Economic History Review, 57, 286-333.

Ogilvie, Sheilagh (2007) "Can We Rehabilitate the Guilds? A Sceptical Re-Appraisal," Cambridge Working Papers in Economics, 0745.

Olson, Mancur (1982) The Rise and Decline of Nations: Economic Growth, Stagflation, and Social Rigidities, New Haven; Yale University Press.

Paine, Thomas (1791/1969) The Rights of Man, Baltimore; Penguin Books.

Palmer, Robert R. (1959) The Age of Democratic Revolution: I The Challenge, Princeton; Princeton University Press. 
Palmer, Robert R. (1964) The Age of Democratic Revolution: II The Struggle, Princeton; Princeton University Press.

Rapp, Richard T. (1976) Industry and the Economic Decline of Seventeenth Century Venice, Cambridge; Harvard University Press.

Rodrik, Dani (2007) One Economics, Many Recipes: Globalization, Institutions, and Economic Growth, Princeton; Princeton University Press.

Rosenthal, Jean-Laurent (1992) The Fruits of Revolution: Property, Litigation and French Agriculture, 1700-1860, New York; Cambridge University Press.

Rudé, Georges (1964) Revolutionary Europe, 1783-1815, Oxford; Blackwell.

Rudé, Georges (1988) The French Revolution, New York; Grove Press.

Schmitt, Hans A. (1983) "Germany without Prussia: A Closer Look at the Confederation of the Rhine," German Studies Review, 6, 9-39.

Simms, Brendan (2004) "Political and Diplomatic Movements, 1800-1830; Napoleon, national uprising, restoration" in Jonathan Sperber ed. The Shorter Oxford History of Germany: Germany 1800-1870, New York; Oxford University Press.

Sperber, Jonathan (1989) "Echoes of the French Revolution in the Rhineland, 18301849." Central European History, 22, 200-17.

Sperber, Jonathan (1991) Rhineland Radicals: The Democratic Movement and the Revolution of 1848-1849, Princeton; Princeton University Press.

Tilly, Richard (1996) "German Industrialization," in Mikuláš Teich and Roy Porter eds. The Industrial Revolution in National Context, New York: Cambridge University Press.

Trebilcock, Clive (1981) The Industrialization of the Continental Powers, 1780-1940, London; Longman.

Weber, Max (1905/1930) The Protestant Ethic and the Spirit of Capitalism, London; Allen and Unwin.

White, Eugene N. (2001) "France and the Failure to Modernize Macroeconomic Institutions," in Michael D. Bordo and Roberto Cortes Conde eds. The Legacy of Western European Fiscal and Monetary Institutions for the New World: The Seventeenth to the Nineteenth Century, New York: Cambridge University Press.

Wooldridge, Jeffrey (2002) Econometric Analysis of Cross Section and Panel Data, Cambridge; The MIT Press.

Woolf, J. Stuart (1991) Napoleon's Integration of Europe, New York; Routledge. 


\section{Appendix A: Data description}

\begin{tabular}{ll} 
Variable & Description - Source \\
\hline \hline $\begin{array}{l}\text { Invaded by French } \\
\text { Revolutionary Armies }\end{array}$ & $\begin{array}{l}\text { Control by French troops or French-appointed rulers during } \\
\text { the Revolutionary period. - Grab (2003). }\end{array}$ \\
\hline $\begin{array}{l}\text { Invaded by Napoleonic } \\
\text { Armies }\end{array}$ & $\begin{array}{l}\text { Control by French troops or French-appointed rulers during } \\
\text { the Napoleonic period. - Grab (2003). }\end{array}$ \\
\hline Latitude & Latitude in degrees of a country's capital. - passim. \\
\hline Log GDP per capita & Log real GDP per capita in 1990 Geary-Khamis dollars. - \\
& Maddison (2003) \\
\hline Protestantism & "1" if the broad majority of a country belongs to a Protes- \\
& tant denomination, "0" if Catholic, "0.5" if no denomination \\
& predominant. - passim. \\
\hline Railways & Length of the railways network in km. - "Statistische \\
& Nachrichten von den preussischen Eisenbahnen" (until 1880) \\
& and "Statistik der im Betriebe befindlichen Eisenbahnen \\
& Deutschlands" (after 1880) \\
\hline Sectoral shares & Share of the population employed in a given sector - Frank \\
& $(1994)$ \\
\hline Urbanization & $\begin{array}{l}\text { Percent of total population living in cities above 5000 inhab- } \\
\text { itants. - See Appendices 6-6. }\end{array}$ \\
\hline Years of French Pres- & Years of presence of French troops or rule by French- \\
ence & appointed rulers. - Grab (2003). \\
\hline
\end{tabular}




\section{Appendix B: Coding Urbanization in German Polities}

In this paper, we use urbanization rates (defined as the ratio of population living in cities above 5,000 inhabitants over total population) for a selection of eight pre-unitary German polities: Hanover, the Rhine province of Prussia, the Westphalian province of Prussia, the rest of Prussia, excluding the far Eastern provinces of East and West Prussia, ${ }^{34}$ Saxony, Baden, Württemberg, and Bavaria.

The definition of these regions follows post-1815 borders. So, for example, Saxony comprises only the part left after its substantial territorial losses in the Congress of Vienna, Hanover comprises East Frisia, Hildesheim, etc., and Bavaria comprises Franconia (but not the Bavarian Palatinate and the territories later lost to Austria, the Hausruckviertel and the Innviertel). For the period before 1800, we have resorted to available evidence on population growth rates in territorial units that roughly corresponded to these post-1815 states, and we have used these rates to project total population numbers back from 1800. In two cases, Hanover and Bavaria, the available evidence on population growth rates from 1700 to 1750 was too weak as to allow us to construct an estimate of total population in 1700. Further details on the construction of the series are available on request.

The total number of people living in cities above 5,000 inhabitants has been computed from the Bairoch, Batou, Chèvre (1988) dataset.

\section{Sources}

Bairoch, Paul, Batou, Jean and Chèvre, Pierre (1988) La population des villes européennes, 800-1850: banque de données et analyse sommaire des résultats, Geneva; Droz.

Behre, Otto (1905) Geschichte der Statistik in Brandenburg-Preussen bis zur Gründung des Königlichen Statistischen Bureaus, Berlin; C. Heymanns.

Blaschke, Karlheinz (1967) Bevölkerungsgeschichte von Sachsen bis zur industriellen Revolution, Weimar; Böhlau.

Boelcke, Willi A. (1987) Wirtschaftsgeschichte Baden-Württembergs: von den Römern bis heute, Stuttgart; K. Theiss.

Conrad, Johannes (1918) Grundriss zum Studium der politischen Oekonomie, vol 4.1. Jena; G. Fischer.

\footnotetext{
${ }^{34}$ East and West Prussia were not part of the Holy Roman Empire before, nor of the German Confederation later
} 
Dahm, Helmut (1951) "Verluste der Jülisch-Bergischen Landmiliz im Dreißigjährigen Krieg.” Düsseldorfer Jahrbuch, vol. 45. Düsseldorf: Düsseldorfer Geschichtsverein.

Hohorst, Gerd (1978) Wirtschaftswachstum und Bevölkerungsentwicklung in Preußen 1816 bis 1914. Dissertation: Westfälische Wilhelms-Universität zu Münster. Available on http://www.histat.gesis.org/

Keyser, Erich (1941) Bevölkerungsgeschichte Deutschlands, 2nd ed. Leipzig; S. Hirzel.

Kaufhold, Karl H. and Denzel, Markus (eds., 1988) Historische Statistik des Kurfürstentums/Königreichs Hannover, St. Katharinen; Scripta Mercaturae.

Königliches statistisches Landesamt (various years) Beiträge zur Statistik des Königreichs Bayern, München.

Lahmeyer, Jan (n.d.) Population statistics: historical demography of all countries, their divisions and towns. http://www.populstat.info/

Lee, W. Robert (1977) Population growth, economic development, and social change in Bavaria, New York; Arno Press.

Mitchell, Brian R. (1988) International historical statistics: Europe, 1750-1993, 4th ed. London; Macmillan.

Sundbärg, Gustav (1905) Aperçus statistiques internationaux, Paris.

\section{Appendix C: Coding Urbanization in Italian Polities}

Equivalently to the case of Germany, we constructed total population figures for 13 pre-unitary Italian polities: Piedmont (including Liguria, but not Sardinia), Lombardy, Venetia, Emilian states (including Parma and Modena), the Papal Legations (what is now part of EmiliaRomagna), Tuscany, the Marche, the Papal State excluding the Papal Legations and the Marche, Naples excluding Sicily, Sicily, and Sardinia. In some cases the definition is grounded in the fact that these were sovereign states (e.g., Tuscany), in other cases we had to break up states according to the length of French occupation (e.g., we divided the Papal State into three parts); in the case of the Emilian states, we chose to aggregate two small states that shared an analogous experience of French rule.

For some periods, we had to adjust our estimates taking into account border changes that occurred between the 18th and the 19th century, for example in the case of the Lomellina (changing hands between Lombardy and Piedmont), or the duchy of Lucca (from Modena to Tuscany). 
Urbanization rates were constructed by dividing the total urban population as from Bairoch, Batou, Chèvre (1988) with the total population figures.

\section{Sources}

Bairoch, Paul, Batou, Jean and Chèvre, Pierre (1988) La population des villes européennes, 800-1850: banque de données et analyse sommaire des résultats, Geneva; Droz.

Bandettini, Pierfrancesco (1960) L'evoluzione demografica della Toscana dal 1810 al 1889, Torino; Industria libraria tipografica editrice.

Bandettini, Pierfrancesco (1961) La popolazione della Toscana dal 1810 al 1959, Firenze; Camera di commercio, industria e agricoltura, Scuola di statistica della universit.

Beltrami, Daniele (1954) Storia della popolazione di Venezia dalla fine del secolo XVI alla caduta della Repubblica, Padova; CEDAM.

Beloch, Julius (1937-1961) Bevölkerungsgeschichte Italiens, Berlin; de Gruyter.

Breschi, Marco (1990) La popolazione della Toscana dal 1640 al 1940: un'ipotesi di ricostruzione, Firenze; Dipartimento statistico-matematico, Università degli studi di Firenze.

Cipolla, Carlo M. (1965) "Four Centuries of Italian Demographic Development." Ch. 24 in: Glass, David V. and Eversley, D.E.C., Population in History: Essays in Historical Demography. London; E. Arnold.

Corridore, Francesco (1906) La popolazione dello Stato romano (1656-1901), Roma: E. Loescher.

Gothaischer Hofkalender: genealogisches Taschenbuch der fürstlichen Häuser (various years), Gotha; J. Perthes.

Felloni, Giuseppe (1961) Popolazione e sviluppo economico della Liguria nel secolo XIX, Torino; Industria libraria tipografica editrice.

Melano, Giuseppe (1961) La popolazione di Torino e del Piemonte nel secolo XIX, Torino; Museo Nazionale del Risorgimento.

Mitchell, Brian R. (1998) International historical statistics: Europe, 1750-1993, 4th ed. London; Macmillan.

Romani, Mario (1950) Un secolo di vita economica Lombarda: 1748-1848, n.p. 


\section{Appendix D: Coding Urbanization after 1850}

For urbanization rates in 1900 we resorted, where possible, to official census data detailing the size of the population living in urban centers above 5000 inhabitants. These were available for the following countries: Germany (including data referring to pre-unitary territorial units), Italy (including data referring to pre-unitary territorial units), Italy, France, Belgium, England and Wales.

For the remaining countries the urbanization rate was computed by adding up the total population residing in cities above 5000 inhabitants from Lahmeyer (populstat.info), and dividing this figure by the total population of a country in its present-day borders. The latter is obtained either from McEvedy and Jones (1978), Lahmeyer (populstat.info) or Maddison (2003).

Additionally, in the case of German pre-unitarian territories, we could construct exact urbanization measures using official census data for the years 1875, 1880, 1885, 1890, 1895, 1900, 1905, 1910. The corresponding data can be retrieved in the various volumes of the Statistik des deutschen Reichs.

\section{Sources}

Census office (1904) Census of England and Wales. (63 Vict. c. 4.) 1901. General report with appendices, London; Darling \& Son.

Direzione generale della statistica (1902-1904) Censimento della popolazione del regno d'Italia al 10 febbraio 1901, vol. 5. Roma; Tipografia nazionale di G. Berte.

Lahmeyer, Jan (n.d.) Population statistics: historical demography of all countries, their divisions and towns, http://www.populstat.info/

Maddison, Angus (2003) The world economy: historical statistics, Paris; Development Centre of the Organisation for Economic Co-operation and Development.

McEvedy, Colin and Jones, Richard (1978) Atlas of world population history, Harmondsworth and New York; Penguin.

Ministère de l'intérieur et de l'instruction publique (1903) Statistique de la Belgique. Population. Recensement général du 31 décembre 1900, Bruxelles; A. Lesigne.

Statistique Générale (1904) Résultats statistiques du recensement général de la population effectué le 24 mars 1901, Paris; Imprimerie nationale.

Statistisches Reichsamt (various years) Statistik des deutschen Reichs, Berlin. 


\section{Appendix E: Coding Institutional Reform in German Polities}

In this appendix, we describe in more detail the introduction of reforms in 19th century Germany; a list of sources is given below. A more detailed description of this process in all German pre-unitary states can be found in Acemoglu et. al. (2009).

The introduction of the French civil and commercial codes was one of the reforms most systematically pursued in the occupied territories of Germany and the civil code, introduced by Napoleon, was in force until 1900 in the territories left of the Rhine. The codes were enacted in the Rhineland starting in 1805, in Westphalia starting in 1808, in the Grand Duchy of Berg starting in 1810, and starting in 1809/1810 for the territories of northern Germany corresponding to present-day Lower Saxony, as well as in the Hanseatic Cities of Bremen, Hamburg, and Lübeck. At the same time, Baden, under the leadership of its liberal prime minister Johann Niklas Friedrich Brauer, introduced the Badisches Landrecht, essentially the Code Napoléon with some minor additions; Bavaria, on the other hand, merely revised some parts of its Codex Maximilianeus Bavaricus Civilis of 1756, which however remained a subsidiary legal source, second to customary law.

After the demise of Napoleonic rule in Germany, the territories east of the Rhine were quick in reintroducing the previous legal systems and dismantling all remnants of the Napoleonic reforms. Two exceptions stand out, though. The lands that were taken over by Prussia obtained the Allgemeines Landrecht (ALR), the ambitious Prussian civil code of 1794, a 19,000 paragraphs-long codification of all legal matters which, while retaining some vestiges of the feudal system, was a progressive work for its times, heavily influenced by the ideals of the Enlightenment. The other exception is represented by the Rhineland, where the local bourgeoisie

successfully defended the presence of the Code Napoléon, evidently favorable to their position.

The abolition of guilds is another reform intimately linked to the abolition of the remnants of the ancien régime. The development mirrors the case of the introduction of the civil code: guilds are first abolished in the territories on the left bank of the Rhine (1800), then in the Napoleonic states of Westphalia (1808) and Berg (1809), finally in Northern Germany. Restoration of the status quo ante occurred equally quickly in the reactionary states of Hannover and Hesse-Kassel between 1814 and 1816. Even the Hanseatic cities reversed the reforms they had been subjected to.

The situation in the Prussian territories was varied: while the Gewerbefreiheit (freedom of commerce, including the abolition of guilds) was a pillar of the reforms of Stein and Hardenberg, 
it extended at first only to the core territories of Prussia at its minimal territorial extension after the Peace of Tilsit. Following the Congress of Vienna, the abolition of guilds was sustained in the Rhineland (both Prussian and non-Prussian) and in the former territories of Berg and Westphalia.

The policies of no other German state were as consistent with freedom of commerce after 1815 as were those of Prussia; Baden retained its guild structure, whereas Württemberg reorganized its guilds in larger units, allowing for a small degree of mobility within groups. Bavaria and Saxony moved instead to a concession-based system, where a state bureaucracy would determine the number of people and the prerequisites to become craftsmen. A temporary backlash occurred during and after the 1848 revolution, when there was pressure for a restoration of guild structures in many states that had so far pursued liberal policies, and full liberalization all over Germany was eventually achieved with the new Gewerbeordnung (law regulating commerce) after unification in 1871.

Agrarian reforms are another dimension along which different approaches are discernible across German states, even when restricting one's view only to the territories west of the Elbe, where the feudal relations were less oppressive than in the eastern territories characterized by serfdom and the Gutsherrschaft form of land tenure. Again, we can see that the wave of reforms was lead by the French occupiers first, and by the Prussian 'defensive modernizers' thereafter. The most radical attempt to reform succeeded only west of the Rhine, where serfdom was abolished without compensation and duties were made redeemable for 15 times their annual value in 1798 .

Reforms followed suit in Berg (1808) and Westphalia (1809), but confusion soon arose about the exact terms of the redemption of feudal payments. All reforms were ultimately blocked by decree in 1812, and resumed only in Prussian times. In fact, at the same time Prussia was already implementing agrarian reforms in parts of Prussia, starting with the edict of October 9th, 1807, which in 1821 was perfected with laws regulating the exact terms of redemption of feudal duties (25 times their annual value).

A law describing the exact amount needed to exit the feudal relation of the Grundherrschaft was a crucial precondition for agrarian reforms that did not remain a dead letter. Hence what the figures in column 5 of Table 2 report is the introduction of such laws, as well as the abolition of serfdom (a mere formality in most territories west of the Elbe).

The emancipation of Jews is the one reform that was pursued less consistently across 
Germany. The initial steps taken in the Napoleonic states - the most liberal policy was enacted in Westphalia - were rapidly circumscribed with the décret infâme of 1808, which limited the occupational choice of Jews in the Rhineland through concession-based system. In a similar fashion, Prussia granted wide-ranging freedoms at first through the law of March 1812, but retreated soon afterwards, when it failed to extend the freedoms to the newly acquired territories. While full emancipation of the Jews, including political rights, had to wait until unification in 1871, some states granted wide-ranging freedoms to their Jewish subjects, in particular with respect to occupational choices. Baden, Brunswick, Anhalt, and the free city of Frankfurt, where the Rothschild dynasty originated, were examples in point.

\section{Sources}

Coing, Helmut (1973) Handbuch der Quellen und Literatur der neueren europäischen Privatrechtsgeschichte, vol. III.3, München; C.H. Beck.

Dipper, Christoph (1980) Die Bauernbefreiung in Deutschland, Stuttgart; Kohlhammer.

Georges, Dirk (1993) 1810/11-1993: Handwerk und Interessenpolitik, Frankfurt am Main; P. Lang.

Lütge, Friedrich (1957) Die mitteldeutsche Grundherrschaft und ihre Auflösung, 2nd ed., Stuttgart; G. Fischer.

Lütge, Friedrich (1963) Geschichte der deutschen Agrarverfassung vom frühen Mittelalter bis zum 19. Jahrhundert, Stuttgart; E. Ulmer.

Mascher, H. (1866) Das deutsche Gewerbewesen von der frühesten Zeit bis auf die Gegenwart, Potsdam; E. Döring.

Meyer, Michael A. (ed., 1996) Deutsch-jüdische Geschichte in der Neuzeit, vol. 2, München; C.H. Beck.

Rönne, Ludwig von and Heinrich Simon (1843) Die früheren und gegenwärtigen Verhältnisse der Juden in den saemmtlichen Landestheilen des Preußischen Staates, Breslau; G.Ph. Aderholz.

Schmoller, Gustav (1870) Zur Geschichte der deutschen Kleingewerbe, Halle; Verlag der Buchhandlung des Waisenhauses.

Schröder, Richard (1905) Lehrbuch der deutschen Rechtsgeschichte, 5th ed., Leipzig; Veit \& Comp. 
Schubert, Werner (1977a) Französisches Recht in Deutschland zu Beginn des 19. Jahrhunderts, Köln; Böhlau.

Schubert, Werner (1977b) "Das französische Recht in Deutschland zu Beginn der Restaurationszeit (1814-1820)," Zeitschrift der Savigny-Stiftung für Rechtsgeschichte, Germanistische Abteilung, 107, 129-184.

Toury, Jacob (1976) Soziale und politische Geschichte der Juden in Deutschland 18471871: Zwischen Revolution, Reaktion und Emanzipation, Düsseldorf; Droste.

Wernet, Karl Friedrich (1963) "Handwerksgeschichtliche Perspektiven," Forschungsberichte aus dem Handwerk, 10. 
Figure 1: Reforms index, Germany

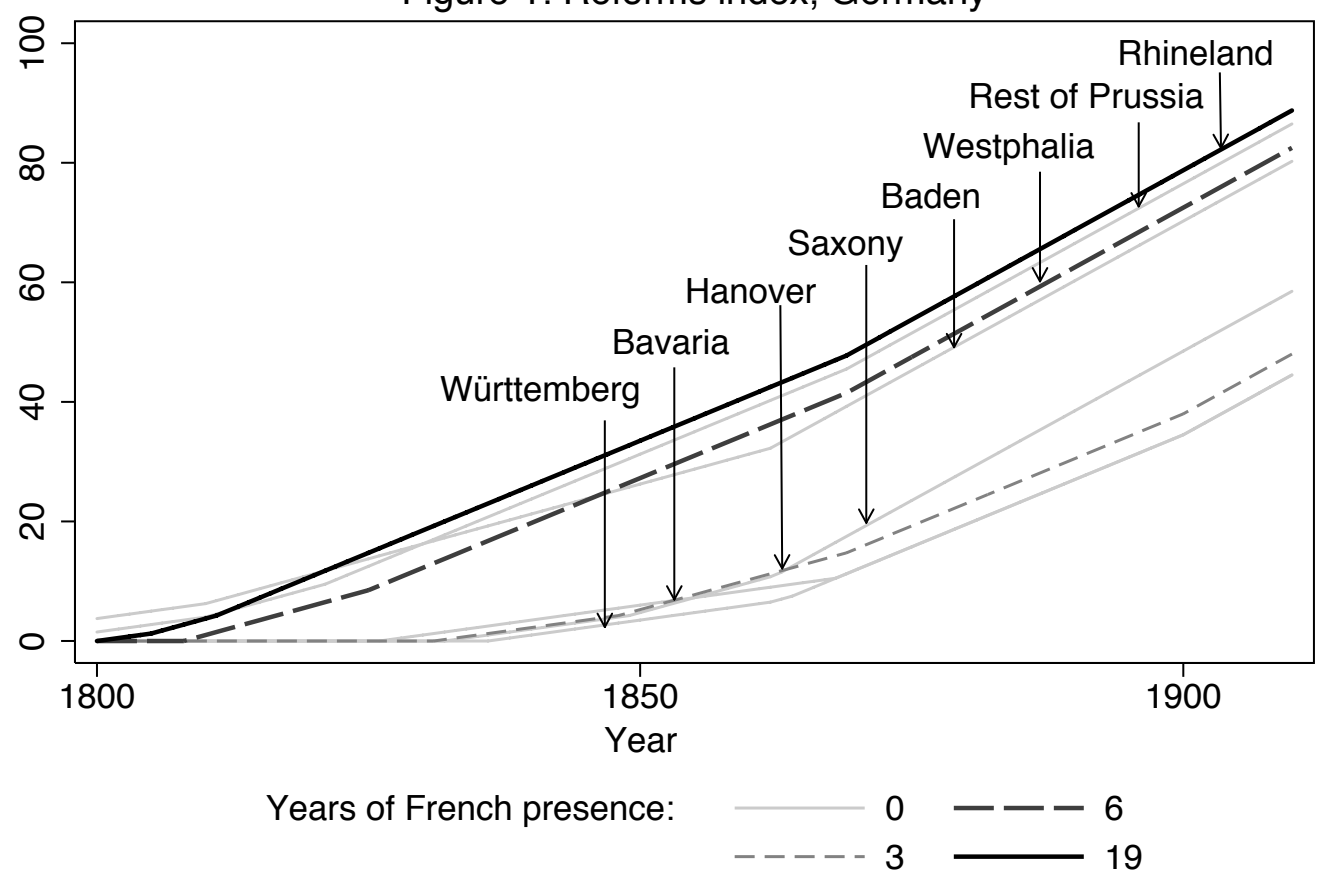


Figure 2A: French Revolutionary Armies as Treatment, European Sample

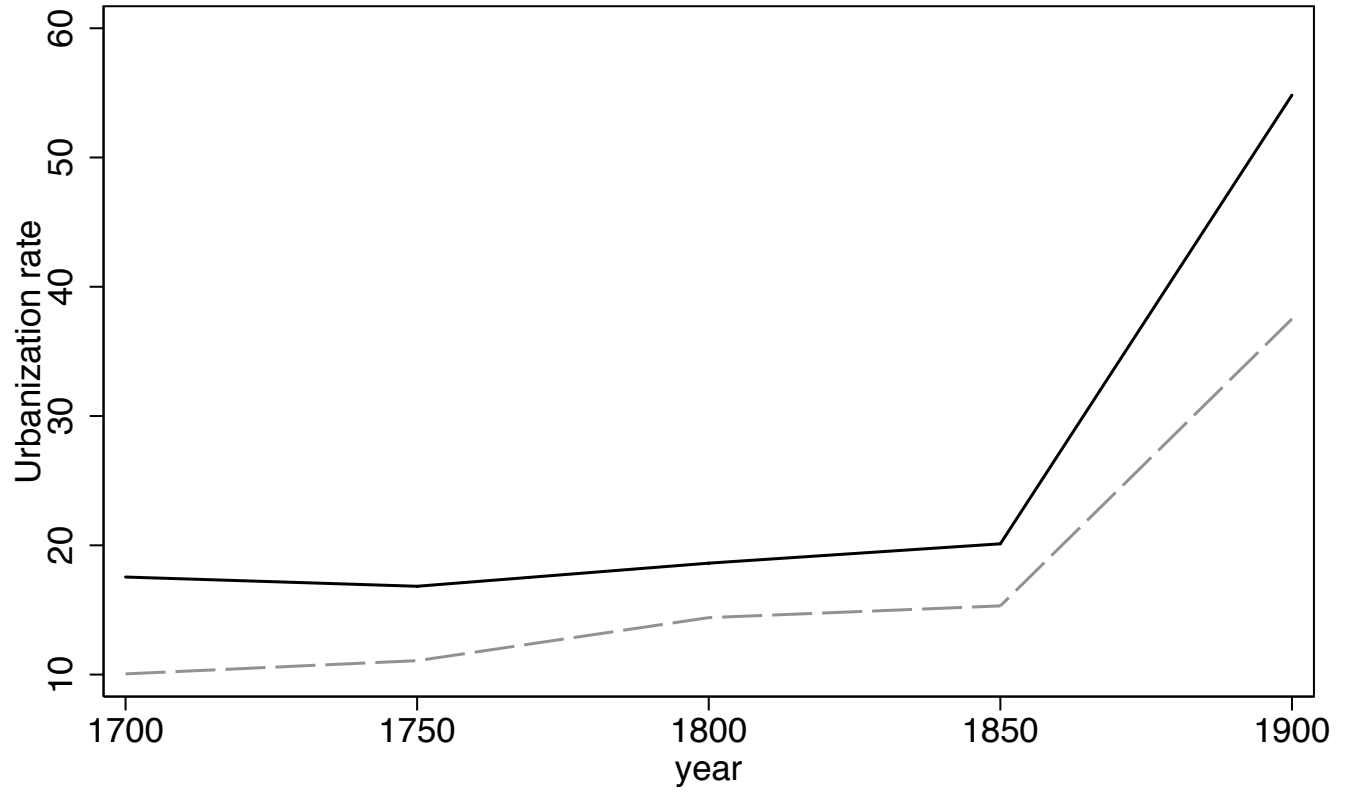

Treatment

Control 
Figure 2B: Napoleonic Armies as Treatment, European Sample

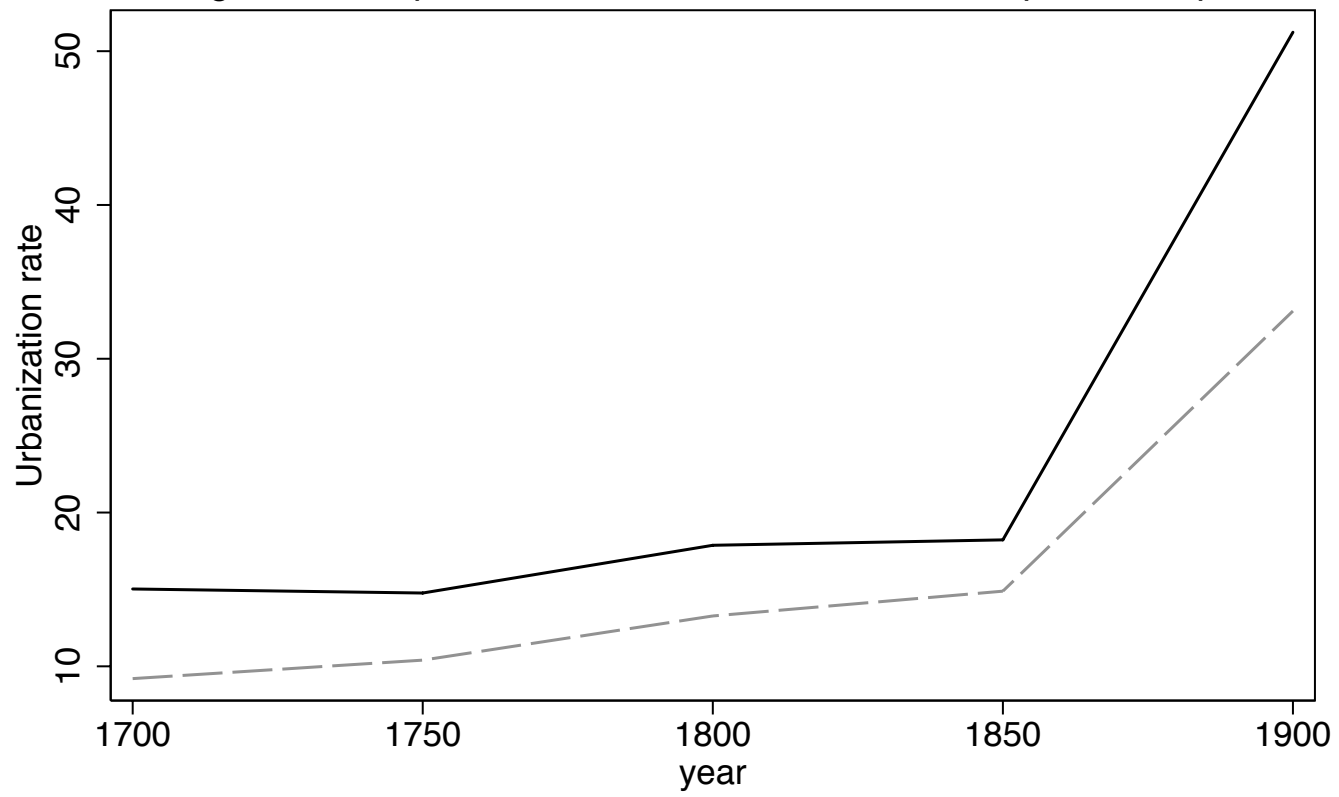

Treatment

Control 
Figure 3A: French Revolutionary Armies as Treatment, German Sample

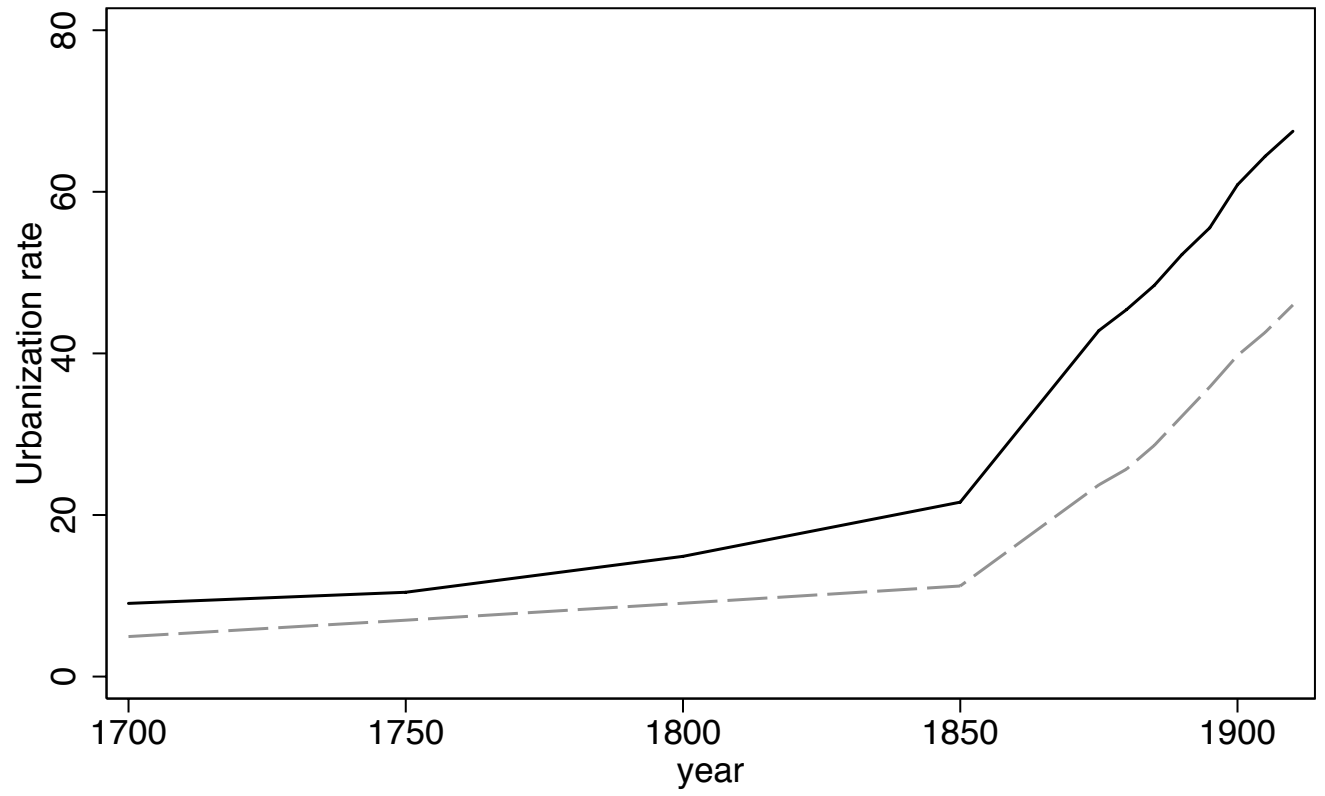

Treatment

Control 
Figure 3B: Napoleonic Armies as Treatment, German Sample

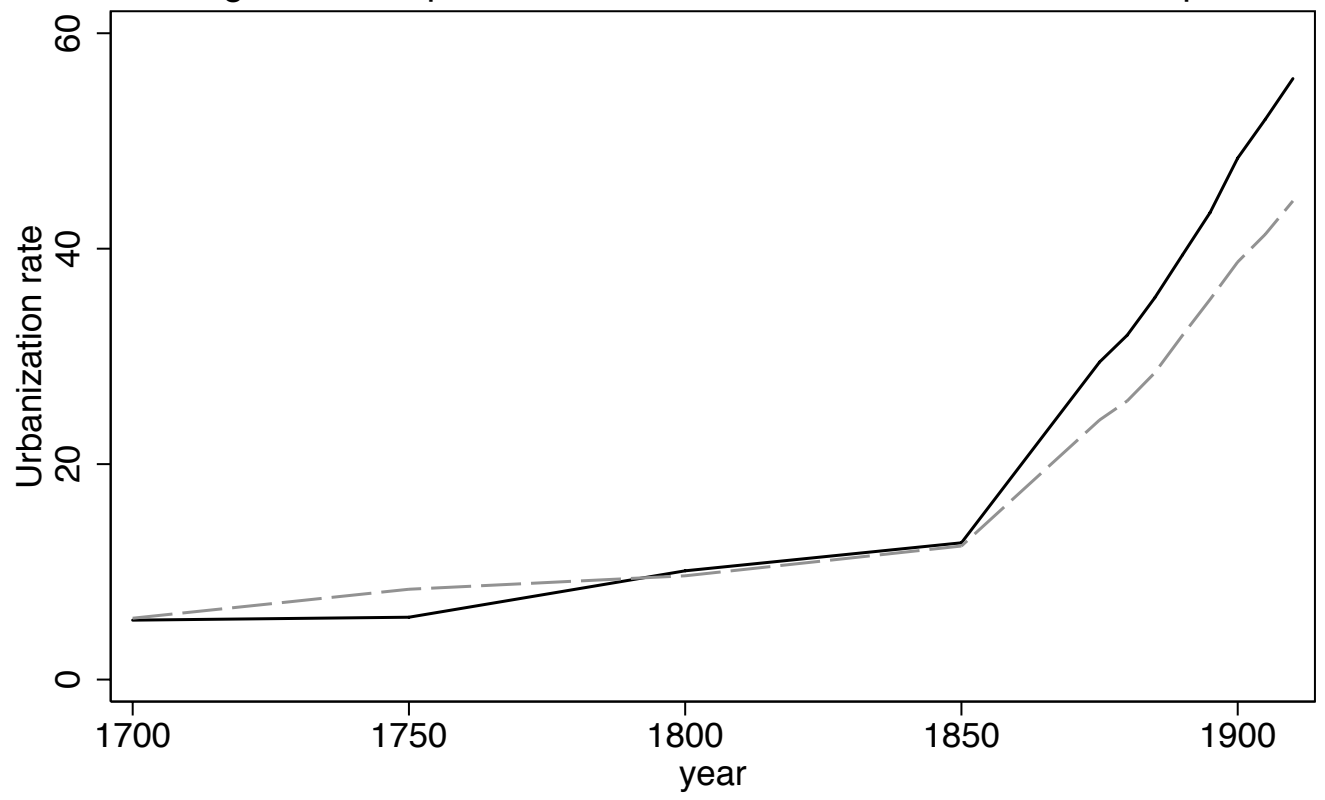

Treatment

Control 
Table 1

Countries in the dataset

\begin{tabular}{|c|c|c|c|c|c|c|}
\hline & $\begin{array}{l}\text { Years of } \\
\text { French } \\
\text { Presence }\end{array}$ & $\begin{array}{c}\text { French Rev. } \\
\text { Armies } \\
\text { Dummy } \\
\end{array}$ & $\begin{array}{c}\text { Napoleonic } \\
\text { Control } \\
\text { Dummy } \\
\end{array}$ & $\begin{array}{l}\text { Beginning of } \\
\text { French } \\
\text { Control } \\
\end{array}$ & $\begin{array}{c}\text { End of French } \\
\text { Control }\end{array}$ & Notes \\
\hline \multicolumn{7}{|l|}{ Western Europe } \\
\hline Austria & 0 & 0 & 0 & & & \\
\hline Belgium & 20 & 1 & 1 & 1794 & 1814 & \\
\hline Britain & 0 & 0 & 0 & & & \\
\hline Czech Republic and Slovakia & 0 & 0 & 0 & & & \\
\hline Denmark & 0 & 0 & 0 & & & \\
\hline Finland & 0 & 0 & 0 & & & \\
\hline Ireland & 0 & 0 & 0 & & & \\
\hline Netherlands & 18 & 1 & 1 & 1795 & 1813 & \\
\hline Norway & 0 & 0 & 0 & & & \\
\hline Portugal & 0 & 0 & 0 & & & \\
\hline Spain & 4 & 0 & 1 & 1809 & 1813 & \\
\hline Sweden & 0 & 0 & 0 & & & \\
\hline Switzerland & 5 & 1 & 1 & 1798 & 1803 & \\
\hline \multicolumn{7}{|l|}{ Germany } \\
\hline Baden & 0 & 0 & 0 & & & \\
\hline Bavaria & 0 & 0 & 0 & & & \\
\hline Hanover & 3 & 0 & 1 & 1810 & 1813 & \\
\hline Prussia, East of Napoleon & 0 & 0 & 0 & & & \\
\hline Prussia, Rhineland & 19 & 1 & 1 & 1795 & 1814 & \\
\hline Prussia, Westphalia & 6 & 0 & 1 & 1807 & 1813 & \\
\hline Saxony & 0 & 0 & 0 & & & \\
\hline Württemberg & 0 & 0 & 0 & & & \\
\hline \multicolumn{7}{|l|}{ Italy } \\
\hline Emilian States & 15 & 1 & 1 & 1801 & 1814 & republic 1797-99 \\
\hline Liguria & 17 & 1 & 1 & 1797 & 1814 & republic 1797-99 \\
\hline Lombardy & 15 & 1 & 1 & 1801 & 1814 & \\
\hline Marche & 6 & 0 & 1 & 1808 & 1814 & \\
\hline Naples & 9 & 0 & 1 & 1806 & 1815 & republic for 5 months \\
\hline Papal Legations & 14 & 1 & 1 & 1802 & 1814 & republic 1797-99 \\
\hline Papal States, Umbria and Lazio & 6 & 0 & 1 & 1809 & 1814 & republic 1798-99 \\
\hline Piedmont & 13 & 0 & 1 & 1802 & 1814 & occupied 1798-99 \\
\hline Sardinia & 0 & 0 & 0 & & & \\
\hline Sicily & 0 & 0 & 0 & & & \\
\hline Tuscany & 6 & 0 & 1 & 1808 & 1814 & \\
\hline Veneto & 8 & 0 & 1 & 1806 & 1814 & \\
\hline \multicolumn{7}{|l|}{ Eastern Europe } \\
\hline Albania & 0 & 0 & 0 & & & \\
\hline Bulgaria & 0 & 0 & 0 & & & \\
\hline Former Yugoslavia & 0 & 0 & 0 & & & \\
\hline Greece & 0 & 0 & 0 & & & \\
\hline Hungary & 0 & 0 & 0 & & & \\
\hline Poland & 6 & 0 & 1 & 1807 & 1813 & \\
\hline Romania & 0 & 0 & 0 & & & \\
\hline Russia & 0 & 0 & 0 & & & \\
\hline
\end{tabular}

Note: Prussia, East of Napoleon, is classified as "Eastern Europe" in the dataset. 
Table 2

Reforms

\begin{tabular}{|c|c|c|c|c|c|c|c|c|c|}
\hline & \multicolumn{3}{|c|}{ Treatment definitions } & \multicolumn{6}{|c|}{ Outcomes } \\
\hline & $\begin{array}{l}\text { French Rev. } \\
\text { Armies }\end{array}$ & $\begin{array}{l}\text { Napoleonic } \\
\text { Armies }\end{array}$ & $\begin{array}{l}\text { Years French } \\
\text { Control }\end{array}$ & Civil Code & $\begin{array}{l}\text { Agrarian } \\
\text { Reform }\end{array}$ & $\begin{array}{l}\text { Abolition of } \\
\text { Guilds }\end{array}$ & $\begin{array}{l}\text { Emancipation } \\
\text { of the Jews }\end{array}$ & $\begin{array}{l}\text { Reforms Index } \\
\text { as of } 1850\end{array}$ & $\begin{array}{l}\text { Reforms Index } \\
\text { as of } 1900\end{array}$ \\
\hline & $(1)$ & $(2)$ & $(3)$ & $(4)$ & $(5)$ & $(6)$ & $(7)$ & $(8)$ & $(8)$ \\
\hline Hanover & 0 & 1 & 3 & 1900 & 1831 & 1869 & 1848 & 4.75 & 25 \\
\hline Prussia (Eastern part) & 0 & 0 & 0 & 1794 & 1821 & 1810 & 1869 & 31.25 & 68.75 \\
\hline Prussia, Rhine Province & 1 & 1 & 19 & 1805 & 1811 & 1800 & 1869 & 33.5 & 71 \\
\hline Prussia, Westphalia & 0 & 1 & 6 & 1808 & 1825 & 1808 & 1869 & 27.25 & 64.75 \\
\hline Saxony & 0 & 0 & 0 & 1863 & 1832 & 1862 & 1849 & 4.5 & 35.75 \\
\hline Baden & 0 & 0 & 0 & 1810 & 1785 & 1862 & 1862 & 26.25 & 60.75 \\
\hline Württemberg & 0 & 0 & 0 & 1900 & 1836 & 1862 & 1864 & 3.5 & 25.5 \\
\hline Bavaria & 0 & 0 & 0 & 1900 & 1826 & 1868 & 1868 & 6 & 26.5 \\
\hline \multirow{2}{*}{\multicolumn{4}{|c|}{$\begin{array}{l}\text { Invaded by French revolutionary armies, average: } \\
\text { Not invaded by French revolutionary armies, average: }\end{array}$}} & 1805 & 1811 & 1800 & 1869 & 33.5 & 71 \\
\hline & & & & 1854 & 1822 & 1849 & 1861 & 14.79 & 43.86 \\
\hline \multicolumn{4}{|c|}{ Invaded by Napoleonic armies, average: } & 1838 & 1822 & 1826 & 1862 & 21.83 & 53.58 \\
\hline \multicolumn{4}{|c|}{ Not invaded by Napoleonic armies, average: } & 1853 & 1820 & 1853 & 1862 & 14.3 & 43.45 \\
\hline \multicolumn{4}{|c|}{ Years of French presence, correlation coefficient: } & -0.3978 & -0.1740 & -0.6610 & 0.3057 & 0.5341 & 0.5054 \\
\hline
\end{tabular}

Notes: Sources for the dates of reform are listed in Appendix B. Averages in the lower panel of this table are unweighted. The reform index in columns (8) and (9) has been computed exemplarily for two dates $(1850,1900)$ according to the formula reported in the text. 
Table 3A

Descriptive Statistics: Europe

\begin{tabular}{|c|c|c|c|c|c|}
\hline & All States & $\begin{array}{c}\text { Invaded by } \\
\text { French Rev. } \\
\text { Armies }\end{array}$ & $\begin{array}{l}\text { Not invaded } \\
\text { by French } \\
\text { Rev. Armies }\end{array}$ & $\begin{array}{c}\text { Invaded by } \\
\text { Napoleonic } \\
\text { Armies }\end{array}$ & $\begin{array}{c}\text { Not invaded } \\
\text { by Napoleonic } \\
\text { Armies }\end{array}$ \\
\hline & (1) & $(2)$ & (3) & (4) & (5) \\
\hline \multicolumn{6}{|l|}{ Panel A: Urbanization dataset } \\
\hline Urbanization in 1700 & $\begin{array}{c}11.819 \\
(11.798)\end{array}$ & $\begin{array}{c}18.703 \\
(9.9)\end{array}$ & $\begin{array}{c}10.042 \\
(11.728)\end{array}$ & $\begin{array}{c}15.278 \\
(9.325)\end{array}$ & $\begin{array}{c}9.146 \\
(12.980)\end{array}$ \\
\hline Urbanization in 1750 & $\begin{array}{c}12.312 \\
(10.958)\end{array}$ & $\begin{array}{l}17.475 \\
(7.624)\end{array}$ & $\begin{array}{c}11.060 \\
(11.363)\end{array}$ & $\begin{array}{l}14.823 \\
(8.085)\end{array}$ & $\begin{array}{c}10.347 \\
(12.595)\end{array}$ \\
\hline Urbanization in 1800 & $\begin{array}{c}15.256 \\
(11.749)\end{array}$ & $\begin{array}{l}18.642 \\
(8.727)\end{array}$ & $\begin{array}{c}14.435 \\
(12.342)\end{array}$ & $\begin{array}{c}17.799 \\
(8.978)\end{array}$ & $\begin{array}{c}13.266 \\
(13.389)\end{array}$ \\
\hline Urbanization in 1850 & $\begin{array}{c}16.295 \\
(11.46)\end{array}$ & $\begin{array}{l}20.484 \\
(7.126)\end{array}$ & $\begin{array}{c}15.279 \\
(12.149)\end{array}$ & $\begin{array}{c}18.178 \\
(7.638)\end{array}$ & $\begin{array}{c}14.821 \\
(13.73)\end{array}$ \\
\hline Urbanization in 1900 & $\begin{array}{c}41.183 \\
(21.241)\end{array}$ & $\begin{array}{c}55.936 \\
(15.458)\end{array}$ & $\begin{array}{c}37.495 \\
(21.058)\end{array}$ & $\begin{array}{c}51.328 \\
(18.235)\end{array}$ & $\begin{array}{c}32.882 \\
(20.207)\end{array}$ \\
\hline Invaded by French Rev. Armies & $\begin{array}{c}0.195 \\
(0.397)\end{array}$ & $\begin{array}{c}1 \\
(0)\end{array}$ & $\begin{array}{c}0 \\
(0)\end{array}$ & $\begin{array}{c}0.444 \\
(0.5)\end{array}$ & $\begin{array}{c}0 \\
(0)\end{array}$ \\
\hline Invaded by Napoleonic Armies & $\begin{array}{c}0.439 \\
(0.497)\end{array}$ & $\begin{array}{c}1 \\
(0)\end{array}$ & $\begin{array}{c}0.333 \\
(0.473)\end{array}$ & $\begin{array}{c}1 \\
(0)\end{array}$ & $\begin{array}{c}0 \\
(0)\end{array}$ \\
\hline Years of French Presence & $\begin{array}{c}4.634 \\
(6.424)\end{array}$ & $\begin{array}{l}15.375 \\
(4.442)\end{array}$ & $\begin{array}{c}2.030 \\
(3.417)\end{array}$ & $\begin{array}{l}10.556 \\
(5.601)\end{array}$ & $\begin{array}{c}0 \\
(0)\end{array}$ \\
\hline Latitude & $\begin{array}{l}47.797 \\
(6.022)\end{array}$ & $\begin{array}{l}47.460 \\
(3.067)\end{array}$ & $\begin{array}{l}47.879 \\
(6.545)\end{array}$ & $\begin{array}{l}46.513 \\
(4.015)\end{array}$ & $\begin{array}{c}48.802 \\
(7.07)\end{array}$ \\
\hline Protestant & $\begin{array}{c}0.268 \\
(0.416)\end{array}$ & $\begin{array}{c}0.125 \\
(0.219)\end{array}$ & $\begin{array}{l}0.303 \\
0.444\end{array}$ & $\begin{array}{c}0.139 \\
(0.281)\end{array}$ & $\begin{array}{c}0.370 \\
(0.473)\end{array}$ \\
\hline Observations (panel) & 205 & 40 & 165 & 90 & 115 \\
\hline \multicolumn{6}{|l|}{ Panel B: GDP per capita dataset } \\
\hline Log GDP per capita in 1700 & $\begin{array}{c}6.701 \\
(0.339)\end{array}$ & $\begin{array}{c}7.063 \\
(0.354)\end{array}$ & $\begin{array}{c}6.595 \\
(0.259)\end{array}$ & $\begin{array}{c}6.924 \\
(0.386)\end{array}$ & $\begin{array}{c}6.597 \\
(0.269)\end{array}$ \\
\hline Log GDP per capita in 1820 & $\begin{array}{c}6.844 \\
(0.326)\end{array}$ & $\begin{array}{c}7.139 \\
(0.226)\end{array}$ & $\begin{array}{c}6.758 \\
(0.302)\end{array}$ & $\begin{array}{c}7.02 \\
(0.297)\end{array}$ & $\begin{array}{c}6.763 \\
(0.315)\end{array}$ \\
\hline Log GDP per capita in 1850 & $\begin{array}{c}7.079 \\
(0.351)\end{array}$ & $\begin{array}{c}7.414 \\
(0.232)\end{array}$ & $\begin{array}{c}6.974 \\
(0.318)\end{array}$ & $\begin{array}{c}7.26 \\
(0.33)\end{array}$ & $\begin{array}{c}6.988 \\
(0.336)\end{array}$ \\
\hline Log GDP per capita in 1900 & $\begin{array}{c}7.601 \\
(0.418)\end{array}$ & $\begin{array}{c}8.021 \\
(0.314)\end{array}$ & $\begin{array}{c}7.477 \\
(0.365)\end{array}$ & $\begin{array}{c}7.837 \\
(0.409)\end{array}$ & $\begin{array}{c}7.49 \\
(0.386)\end{array}$ \\
\hline Invaded by French Rev. Armies & $\begin{array}{c}0.227 \\
(0.420)\end{array}$ & $\begin{array}{c}1 \\
(0)\end{array}$ & $\begin{array}{c}0 \\
(0)\end{array}$ & $\begin{array}{c}0.714 \\
(0.456)\end{array}$ & $\begin{array}{c}0 \\
(0)\end{array}$ \\
\hline Invaded by Napoleonic Armies & $\begin{array}{c}0.318 \\
(0.467)\end{array}$ & $\begin{array}{c}1 \\
(0)\end{array}$ & $\begin{array}{c}0.118 \\
(0.323)\end{array}$ & $\begin{array}{c}1 \\
(0)\end{array}$ & $\begin{array}{c}0 \\
(0)\end{array}$ \\
\hline Year of French Presence & $\begin{array}{c}2.955 \\
(5.653)\end{array}$ & $\begin{array}{c}11 \\
(6.928)\end{array}$ & $\begin{array}{c}0.588 \\
(1.653)\end{array}$ & $\begin{array}{c}9.286 \\
(6.466)\end{array}$ & $\begin{array}{c}0 \\
(0)\end{array}$ \\
\hline Latitude & $\begin{array}{l}48.957 \\
(6.914)\end{array}$ & $\begin{array}{l}48.433 \\
(3.762)\end{array}$ & $\begin{array}{l}49.110 \\
(7.601)\end{array}$ & $\begin{array}{l}47.826 \\
(4.596)\end{array}$ & $\begin{array}{l}49.484 \\
(7.724)\end{array}$ \\
\hline Protestant & $\begin{array}{c}0.273 \\
(0.420)\end{array}$ & $\begin{array}{c}0.200 \\
(0.248)\end{array}$ & $\begin{array}{c}0.294 \\
(0.457)\end{array}$ & $\begin{array}{c}0.143 \\
(0.228)\end{array}$ & $\begin{array}{c}0.333 \\
(0.473)\end{array}$ \\
\hline Observations (panel) & 176 & 40 & 136 & 56 & 120 \\
\hline
\end{tabular}


Table 3B

Descriptive Statistics: Germany

\begin{tabular}{|c|c|c|c|c|c|}
\hline & All States & $\begin{array}{c}\text { Invaded by } \\
\text { French Rev. } \\
\text { Armies }\end{array}$ & $\begin{array}{l}\text { Not invaded } \\
\text { by French } \\
\text { Rev. Armies }\end{array}$ & $\begin{array}{l}\text { Invaded by } \\
\text { Napoleonic } \\
\text { Armies }\end{array}$ & $\begin{array}{c}\text { Not invaded } \\
\text { by Napoleonic } \\
\text { Armies }\end{array}$ \\
\hline & (1) & (2) & (3) & (4) & (5) \\
\hline \multicolumn{6}{|l|}{ German urbanization dataset } \\
\hline Urbanization in 1700 & $\begin{array}{l}5.639 \\
(3.14)\end{array}$ & $\begin{array}{c}9.061 \\
.\end{array}$ & $\begin{array}{c}4.955 \\
(2.968)\end{array}$ & $\begin{array}{c}5.521 \\
(5.007)\end{array}$ & $\begin{array}{c}5.698 \\
(2.839)\end{array}$ \\
\hline Urbanization in 1750 & $\begin{array}{c}7.414 \\
(4.319)\end{array}$ & $\begin{array}{c}10.437 \\
.\end{array}$ & $\begin{array}{c}6.982 \\
(4.475)\end{array}$ & $\begin{array}{c}5.791 \\
(4.152)\end{array}$ & $\begin{array}{c}8.387 \\
(4.568)\end{array}$ \\
\hline Urbanization in 1800 & $\begin{array}{c}9.810 \\
(3.547)\end{array}$ & $\begin{array}{c}14.883 \\
.\end{array}$ & $\begin{array}{c}9.086 \\
(3.126)\end{array}$ & $\begin{array}{l}10.099 \\
(4.278)\end{array}$ & $\begin{array}{c}9.637 \\
(3.572)\end{array}$ \\
\hline Urbanization in 1850 & $\begin{array}{c}12.514 \\
(5.254)\end{array}$ & $\begin{array}{c}21.594 \\
.\end{array}$ & $\begin{array}{l}11.217 \\
(4.062)\end{array}$ & $\begin{array}{l}12.700 \\
(7.717)\end{array}$ & $\begin{array}{l}12.402 \\
(4.299)\end{array}$ \\
\hline Urbanization in 1900 & $\begin{array}{c}42.382 \\
(14.084)\end{array}$ & $\begin{array}{c}60.872 \\
.\end{array}$ & $\begin{array}{c}39.741 \\
(12.896)\end{array}$ & $\begin{array}{c}48.409 \\
(15.380)\end{array}$ & $\begin{array}{c}38.766 \\
(13.612)\end{array}$ \\
\hline Invaded by French Rev. Armies & $\begin{array}{c}0.125 \\
(0.332)\end{array}$ & $\begin{array}{l}1 \\
.\end{array}$ & $\begin{array}{c}0 \\
(0)\end{array}$ & $\begin{array}{c}0.33 \\
(0.478)\end{array}$ & $\begin{array}{c}0 \\
(0)\end{array}$ \\
\hline Invaded by Napoleonic Armies & $\begin{array}{c}0.5 \\
(0.503)\end{array}$ & 1 & $\begin{array}{c}0.429 \\
(0.498)\end{array}$ & $\begin{array}{c}1 \\
(0)\end{array}$ & $\begin{array}{c}0 \\
(0)\end{array}$ \\
\hline Years of French Presence & $\begin{array}{c}3.5 \\
(6.237)\end{array}$ & $\begin{array}{c}19 \\
.\end{array}$ & $\begin{array}{c}1.286 \\
(2.198)\end{array}$ & $\begin{array}{c}9.333 \\
(7.043)\end{array}$ & $\begin{array}{c}0 \\
(0)\end{array}$ \\
\hline Observations (panel) & 96 & 12 & 84 & 36 & 60 \\
\hline
\end{tabular}

Notes: Mean values. Standard deviations in parentheses. The number of observations refers to the total observations in the panel, not to a single cross-section. For the summary statistics of urbanization, only a selection of years is shown. Only the Rhine Province is invaded by the French Revolutionary Armies. 
Table 4

Country Level Impact of French Revolution: Urbanization

\begin{tabular}{|c|c|c|c|c|}
\hline \multicolumn{5}{|c|}{ Dependent variable: Urbanization (Percent living in cities above 5000 inh.) } \\
\hline & $\begin{array}{c}\text { Fixed Effects } \\
\text { OLS } \\
(1)\end{array}$ & $\begin{array}{c}\text { Fixed Effects } \\
\text { OLS } \\
(2)\end{array}$ & $\begin{array}{c}\begin{array}{c}\text { Fixed Effects } \\
\text { OLS }\end{array} \\
(3)\end{array}$ & $\begin{array}{c}\text { Weighted } \\
\text { Fixed Effects } \\
\text { OLS } \\
(4)\end{array}$ \\
\hline $\begin{array}{l}\text { French Revolution } \\
\text { x } 1750 \text { year dummy }\end{array}$ & $\begin{array}{l}-0.161 \\
{[0.091]}\end{array}$ & $\begin{array}{l}-2.625 \\
{[1.292]}\end{array}$ & $\begin{array}{l}-1.026 \\
{[2.121]}\end{array}$ & $\begin{array}{l}-0.235 \\
{[0.090]}\end{array}$ \\
\hline $\begin{array}{l}\text { French Revolution } \\
\text { x } 1800 \text { year dummy }\end{array}$ & $\begin{array}{l}-0.189 \\
{[0.116]}\end{array}$ & $\begin{array}{l}-4.832 \\
{[1.520]}\end{array}$ & $\begin{array}{l}-0.969 \\
{[2.179]}\end{array}$ & $\begin{array}{l}-0.200 \\
{[0.169]}\end{array}$ \\
\hline French Revolution & -0.236 & -3.835 & -2.145 & -0.289 \\
\hline x 1850 year dummy & [0.154] & [2.385] & {$[2.218]$} & {$[0.207]$} \\
\hline French Revolution & 0.899 & 9.521 & 13.081 & 0.662 \\
\hline x 1900 year dummy & {$[0.382]$} & {$[6.154]$} & [5.162] & {$[0.513]$} \\
\hline $\begin{array}{l}\text { p-value for joint significance } \\
\text { "French Revolution" after } 1800\end{array}$ & 0.001 & 0.037 & 0.006 & 0.000 \\
\hline Definition of treatment & $\begin{array}{l}\text { Years of } \\
\text { French } \\
\text { Presence }\end{array}$ & $\begin{array}{c}\text { French Rev. } \\
\text { Armies } \\
\text { Dummy }\end{array}$ & $\begin{array}{c}\text { Napoleonic } \\
\text { Control } \\
\text { Dummy }\end{array}$ & $\begin{array}{l}\text { Years of } \\
\text { French } \\
\text { Presence }\end{array}$ \\
\hline Observations & 202 & 202 & 202 & 202 \\
\hline Countries & 41 & 41 & 41 & 41 \\
\hline R-squared & 0.87 & 0.86 & 0.88 & 0.85 \\
\hline
\end{tabular}


Table 5

Country Level Impact of French Revolution: Urbanization

\begin{tabular}{|c|c|c|c|c|c|}
\hline \multicolumn{6}{|c|}{ Dependent variable: Urbanization (Percent living in cities above 5000 inh.) } \\
\hline & $\begin{array}{c}\text { Fixed Effects } \\
\text { OLS } \\
(1)\end{array}$ & $\begin{array}{c}\text { Fixed Effects } \\
\text { OLS } \\
(2)\end{array}$ & $\begin{array}{c}\text { Fixed Effects } \\
\text { OLS } \\
(3)\end{array}$ & $\begin{array}{c}\text { Fixed Effects } \\
\text { OLS } \\
(4)\end{array}$ & $\begin{array}{c}\text { Fixed Effects } \\
\text { OLS } \\
\text { (5) }\end{array}$ \\
\hline $\begin{array}{l}\text { French Revolution } \\
\times 1750 \text { year dummy }\end{array}$ & $\begin{array}{c}-0.161 \\
{[0.091]}\end{array}$ & $\begin{array}{c}-0.158 \\
{[0.096]}\end{array}$ & $\begin{array}{c}-0.161 \\
{[0.091]}\end{array}$ & $\begin{array}{c}-0.136 \\
{[0.105]}\end{array}$ & $\begin{array}{c}-0.129 \\
{[0.104]}\end{array}$ \\
\hline $\begin{array}{l}\text { French Revolution } \\
\times 1800 \text { year dummy }\end{array}$ & $\begin{array}{l}-0.189 \\
{[0.116]}\end{array}$ & $\begin{array}{l}-0.203 \\
{[0.115]}\end{array}$ & $\begin{array}{l}-0.197 \\
{[0.120]}\end{array}$ & $\begin{array}{l}-0.194 \\
{[0.115]}\end{array}$ & $\begin{array}{l}-0.153 \\
{[0.120]}\end{array}$ \\
\hline $\begin{array}{l}\text { French Revolution } \\
\text { x } 1850 \text { year dummy }\end{array}$ & $\begin{array}{l}-0.236 \\
{[0.154]}\end{array}$ & $\begin{array}{l}-0.234 \\
{[0.155]}\end{array}$ & $\begin{array}{l}-0.214 \\
{[0.163]}\end{array}$ & $\begin{array}{l}-0.192 \\
{[0.153]}\end{array}$ & $\begin{array}{l}-0.143 \\
{[0.161]}\end{array}$ \\
\hline $\begin{array}{l}\text { French Revolution } \\
\text { x } 1900 \text { year dummy }\end{array}$ & $\begin{array}{c}0.899 \\
{[0.382]}\end{array}$ & $\begin{array}{c}0.914 \\
{[0.394]}\end{array}$ & $\begin{array}{c}0.847 \\
{[0.396]}\end{array}$ & $\begin{array}{c}1.137 \\
{[0.422]}\end{array}$ & $\begin{array}{c}1.169 \\
{[0.400]}\end{array}$ \\
\hline $\begin{array}{l}\text { p-value for joint significance } \\
\text { "French Revolution" after } 1800\end{array}$ & 0.001 & 0.001 & 0.002 & 0.001 & 0.001 \\
\hline $\begin{array}{l}\text { p-value for joint significance of } \\
\text { "latitude" interactions }\end{array}$ & & 0.064 & & & 0.332 \\
\hline $\begin{array}{l}\text { p-value for joint significance of } \\
\text { "initial urbanization" interactions }\end{array}$ & & & 0.359 & & 0.563 \\
\hline $\begin{array}{l}\text { p-value for joint significance of } \\
\text { "protestantism" interactions }\end{array}$ & & & & 0.055 & 0.114 \\
\hline Definition of treatment & $\begin{array}{l}\text { Years of } \\
\text { French } \\
\text { Presence }\end{array}$ & $\begin{array}{l}\text { Years of } \\
\text { French } \\
\text { Presence }\end{array}$ & $\begin{array}{l}\text { Years of } \\
\text { French } \\
\text { Presence }\end{array}$ & $\begin{array}{l}\text { Years of } \\
\text { French } \\
\text { Presence }\end{array}$ & $\begin{array}{l}\text { Years of } \\
\text { French } \\
\text { Presence }\end{array}$ \\
\hline Observations & 202 & 202 & 202 & 202 & 202 \\
\hline Countries & 41 & 41 & 41 & 41 & 41 \\
\hline R-squared & 0.87 & 0.88 & 0.88 & 0.88 & 0.89 \\
\hline
\end{tabular}

Notes: Country level data (pre-unitarian polities for Italy and Germany); all regressions have full set of country and year dummies. Robust standard errors, clustered by country/polity. Base sample is all West and East European countries (except France). Data sources: see Appendix. 
Table 6

Country Level Impact of French Revolution: Urbanization

\begin{tabular}{|c|c|c|c|c|c|c|c|c|}
\hline \multicolumn{9}{|c|}{ Dependent variable: Urbanization (Percent living in cities above 5000 inh.) } \\
\hline & $\begin{array}{c}\text { Fixed Effects } \\
\text { OLS } \\
\end{array}$ & $\begin{array}{c}\text { Fixed Effects } \\
\text { OLS } \\
\end{array}$ & $\begin{array}{c}\text { Fixed Effects } \\
\text { OLS } \\
\end{array}$ & $\begin{array}{c}\text { Fixed Effects } \\
\text { OLS } \\
\end{array}$ & $\begin{array}{c}\text { Arellano- } \\
\text { Bond GMM }\end{array}$ & $\begin{array}{c}\text { Arellano- } \\
\text { Bond GMM }\end{array}$ & $\begin{array}{c}\text { Arellano- } \\
\text { Bond GMM }\end{array}$ & $\begin{array}{l}\text { Arellano- } \\
\text { Bond GMM }\end{array}$ \\
\hline & $(1)$ & $(2)$ & & (4) & (5) & (b) & (8) & (1) \\
\hline $\begin{array}{l}\text { French Revolution } \\
\text { x } 1750 \text { year dummy }\end{array}$ & $\begin{array}{l}-0.161 \\
{[0.091]}\end{array}$ & $\begin{array}{l}-0.152 \\
{[0.092]}\end{array}$ & $\begin{array}{c}-0.192 \\
{[0.089]}\end{array}$ & $\begin{array}{l}-0.345 \\
{[0.091]}\end{array}$ & & & & \\
\hline $\begin{array}{l}\text { French Revolution } \\
\text { x } 1800 \text { year dummy }\end{array}$ & $\begin{array}{l}-0.189 \\
{[0.116]}\end{array}$ & $\begin{array}{l}-0.159 \\
{[0.113]}\end{array}$ & $\begin{array}{l}-0.133 \\
{[0.118]}\end{array}$ & $\begin{array}{l}-0.353 \\
{[0.140]}\end{array}$ & $\begin{array}{c}0.838 \\
{[0.69]}\end{array}$ & $\begin{array}{c}0.53 \\
{[0.49]}\end{array}$ & $\begin{array}{l}0.532 \\
{[0.73]}\end{array}$ & $\begin{array}{l}0.522 \\
{[0.42]}\end{array}$ \\
\hline $\begin{array}{l}\text { French Revolution } \\
\text { x } 1850 \text { year dummy }\end{array}$ & $\begin{array}{l}-0.236 \\
{[0.154]}\end{array}$ & $\begin{array}{c}-0.179 \\
{[0.144]}\end{array}$ & $\begin{array}{l}-0.157 \\
{[0.148]}\end{array}$ & $\begin{array}{c}-0.31 \\
{[0.094]}\end{array}$ & $\begin{array}{l}-0.100 \\
{[0.43]}\end{array}$ & $\begin{array}{l}-0.302 \\
{[0.32]}\end{array}$ & $\begin{array}{l}0.125 \\
{[0.61]}\end{array}$ & $\begin{array}{l}0.141 \\
{[0.22]}\end{array}$ \\
\hline $\begin{array}{l}\text { French Revolution } \\
\text { x } 1900 \text { year dummy }\end{array}$ & 0.899 & 1.001 & 0.742 & 0.283 & 1.057 & 0.878 & 1.014 & 0.705 \\
\hline $\begin{array}{l}\text { x } 1900 \text { year dummy } \\
\text { Lagged dependent variable }\end{array}$ & {$[0.382]$} & {$[0.3 / 4]$} & [0.383] & {$[0.227]$} & $\begin{array}{l}{[0.38]} \\
0.511 \\
{[1.00]}\end{array}$ & $\begin{array}{l}{[0.33]} \\
0.126 \\
{[0.69]}\end{array}$ & $\begin{array}{c}{[0.68]} \\
0.787 \\
{[1.17]}\end{array}$ & $\begin{array}{c}{[0.33]} \\
0.629 \\
{[0.72]}\end{array}$ \\
\hline $\begin{array}{l}\text { p-value for joint significance } \\
\text { "French Revolution" after } 1800\end{array}$ & 0.001 & 0.001 & 0.014 & 0.004 & 0.000 & 0.001 & 0.018 & 0.013 \\
\hline Definition of treatment & $\begin{array}{l}\text { Years of } \\
\text { French } \\
\text { Presence }\end{array}$ & $\begin{array}{l}\text { Years of } \\
\text { French } \\
\text { Presence }\end{array}$ & $\begin{array}{l}\text { Years of } \\
\text { French } \\
\text { Presence }\end{array}$ & $\begin{array}{l}\text { Years of } \\
\text { French } \\
\text { Presence }\end{array}$ & $\begin{array}{l}\text { Years of } \\
\text { French } \\
\text { Presence }\end{array}$ & $\begin{array}{l}\text { Years of } \\
\text { French } \\
\text { Presence }\end{array}$ & $\begin{array}{l}\text { Years of } \\
\text { French } \\
\text { Presence }\end{array}$ & $\begin{array}{l}\text { Years of } \\
\text { French } \\
\text { Presence }\end{array}$ \\
\hline Excluding the UK & $\mathrm{N}$ & $\mathrm{Y}$ & $\mathrm{Y}$ & $\mathrm{Y}$ & $\mathrm{N}$ & $\mathrm{Y}$ & $\mathrm{Y}$ & $\mathrm{Y}$ \\
\hline Excluding Eastern Europe & $\mathrm{N}$ & $\mathrm{N}$ & $\mathrm{Y}$ & $\mathrm{N}$ & $\mathrm{N}$ & $\mathrm{N}$ & $\mathrm{Y}$ & $\mathrm{N}$ \\
\hline Excluding Italy and Germany & $\mathrm{N}$ & $\mathrm{N}$ & $\mathrm{N}$ & Y & $\mathrm{N}$ & $\mathrm{N}$ & $\mathrm{N}$ & Y \\
\hline Observations & 202 & 197 & 152 & 99 & 120 & 117 & 90 & 59 \\
\hline Countries & 41 & 40 & 31 & 20 & 41 & 40 & 31 & 20 \\
\hline R-squared & 0.87 & 0.88 & 0.9 & 0.85 & & & & \\
\hline
\end{tabular}

Notes: Country level data (pre-unitarian polities for Italy and Germany); all regressions have full set of country and year dummies. Robust standard errors, clustered by country/polity. Base sample is all West and East European countries (except France). Data sources: see Appendix. 
Table 7

Country Level Impact of French Revolution: GDP per capita

\begin{tabular}{|c|c|c|c|c|c|c|c|}
\hline \multicolumn{8}{|c|}{ Dependent variable: log GDP per capita } \\
\hline & $\begin{array}{c}\text { Fixed Effects } \\
\text { OLS }\end{array}$ & $\begin{array}{c}\text { Fixed Effects } \\
\text { OLS }\end{array}$ & $\begin{array}{c}\text { Fixed Effects } \\
\text { OLS }\end{array}$ & $\begin{array}{c}\text { Fixed Effects } \\
\text { OLS }\end{array}$ & $\begin{array}{c}\text { Fixed Effects } \\
\text { OLS }\end{array}$ & $\begin{array}{c}\text { Fixed Effects } \\
\text { OLS }\end{array}$ & $\begin{array}{c}\text { Fixed Effects } \\
\text { OLS }\end{array}$ \\
\hline & (1) & (2) & $(3)$ & (4) & (5) & (6) & $(7)$ \\
\hline French Revolution & 0.122 & 0.203 & 0.09 & 0.095 & 0.131 & 0.122 & 0.135 \\
\hline x 1700 year dummy & {$[0.102]$} & {$[0.146]$} & {$[0.108]$} & [0.099] & [0.103] & [0.112] & {$[0.105]$} \\
\hline French Revolution & 0.042 & 0.106 & 0.022 & 0.008 & 0.057 & 0.031 & 0.028 \\
\hline x 1820 year dummy & {$[0.049]$} & {$[0.066]$} & {$[0.065]$} & {$[0.062]$} & {$[0.048]$} & {$[0.051]$} & {$[0.050]$} \\
\hline French Revolution & 0.088 & 0.204 & 0.054 & 0.05 & 0.108 & 0.097 & 0.074 \\
\hline x 1850 year dummy & {$[0.043]$} & {$[0.056]$} & {$[0.095]$} & {$[0.064]$} & {$[0.038]$} & {$[0.045]$} & {$[0.078]$} \\
\hline French Revolution & 0.164 & 0.371 & 0.139 & 0.118 & 0.191 & 0.169 & 0.134 \\
\hline x 1870 year dummy & {$[0.042]$} & {$[0.064]$} & {$[0.140]$} & {$[0.073]$} & {$[0.031]$} & {$[0.038]$} & {$[0.087]$} \\
\hline French Revolution & 0.152 & 0.392 & 0.169 & 0.093 & 0.179 & 0.164 & 0.136 \\
\hline x 1890 year dummy & {$[0.047]$} & {$[0.106]$} & {$[0.147]$} & {$[0.084]$} & {$[0.039]$} & {$[0.048]$} & {$[0.109]$} \\
\hline French Revolution & 0.116 & 0.359 & 0.141 & 0.054 & 0.141 & 0.114 & 0.1 \\
\hline x 1900 year dummy & {$[0.054]$} & {$[0.142]$} & {$[0.156]$} & {$[0.090]$} & {$[0.049]$} & {$[0.058]$} & {$[0.121]$} \\
\hline $\begin{array}{l}\mathrm{p} \text {-value for joint significance of } \\
\text { post-1820 treatment interactions }\end{array}$ & 0.000 & 0.000 & 0.136 & 0.000 & 0.000 & 0.000 & 0.028 \\
\hline Definition of treatment & $\begin{array}{l}\text { Years of } \\
\text { French } \\
\text { Presence }\end{array}$ & $\begin{array}{c}\text { French Rev. } \\
\text { Armies } \\
\text { Dummy }\end{array}$ & $\begin{array}{l}\text { Napoleonic } \\
\text { Control } \\
\text { Dummy }\end{array}$ & $\begin{array}{l}\text { Years of } \\
\text { French } \\
\text { Presence }\end{array}$ & $\begin{array}{l}\text { Years of } \\
\text { French } \\
\text { Presence }\end{array}$ & $\begin{array}{l}\text { Years of } \\
\text { French } \\
\text { Presence }\end{array}$ & $\begin{array}{l}\text { Years of } \\
\text { French } \\
\text { Presence }\end{array}$ \\
\hline Excluding Italy and Germany & $\mathrm{Y}$ & $\mathrm{Y}$ & Y & $\mathrm{N}$ & $\mathrm{Y}$ & $\mathrm{Y}$ & $\mathrm{Y}$ \\
\hline Excluding the UK & $\mathrm{N}$ & $\mathrm{N}$ & $\mathrm{N}$ & $\mathrm{N}$ & $\mathrm{Y}$ & $\mathrm{Y}$ & $\mathrm{N}$ \\
\hline Excluding Eastern Europe & $\mathrm{N}$ & $\mathrm{N}$ & $\mathrm{N}$ & $\mathrm{N}$ & $\mathrm{N}$ & $\mathrm{Y}$ & $\mathrm{N}$ \\
\hline Including latitude, protestant, initial GDP & $\mathrm{N}$ & $\mathrm{N}$ & $\mathrm{N}$ & $\mathrm{N}$ & $\mathrm{N}$ & $\mathrm{N}$ & Y \\
\hline Observations & 158 & 158 & 158 & 174 & 150 & 96 & 158 \\
\hline Countries & 0.96 & 0.96 & 0.96 & 0.95 & 0.97 & 0.96 & 0.97 \\
\hline R-squared & 20 & 20 & 20 & 22 & 19 & 12 & 20 \\
\hline
\end{tabular}

Notes: Country level data (pre-unitarian states for Italy and Germany); all regressions have full set of country and year dummies. Robust standard errors, clustered by country. "Years of French Presence" is measured in decades (years/10). Controls (latitude, protestant, initial GDP in 1500) are included as a full set of interactions with time dummies. Base sample is all West and East European countries (except France). Data are from Maddison (2003). 
Table 8

Within-Germany Impact of French Revolution: Urbanization in 8 regions Dependent variable: Urbanization (Percent living in cities above 5000 inh.)

\begin{tabular}{|c|c|c|c|c|c|c|c|c|c|}
\hline \multicolumn{10}{|c|}{ Dependent variable: Urbanization (Percent living in cities above 5000 inh.) } \\
\hline & $\begin{array}{l}\text { Fixed Effects } \\
\text { OLS }\end{array}$ & $\begin{array}{l}\text { Fixed Effects } \\
\text { OLS }\end{array}$ & $\begin{array}{l}\text { Fixed Effects } \\
\text { OLS }\end{array}$ & $\begin{array}{c}\text { Fixed Effects } \\
\text { OLS, west of } \\
\text { Elbe }\end{array}$ & $\begin{array}{l}\text { Fixed Effects } \\
\text { OLS }\end{array}$ & $\begin{array}{l}\text { Fixed Effects } \\
\text { OLS }\end{array}$ & $\begin{array}{l}\text { Fixed Effects } \\
\text { OLS }\end{array}$ & $\begin{array}{c}\text { Weighted } \\
\text { Fixed Effects } \\
\text { OLS }\end{array}$ & $\begin{array}{l}\text { Arellano- } \\
\text { Bond GMM }\end{array}$ \\
\hline & $(1)$ & $(2)$ & $(3)$ & $(4)$ & $(5)$ & $(6)$ & $(7)$ & $(8)$ & (9) \\
\hline $\begin{array}{l}\text { French Revolution } \\
\text { x } 1750 \text { year dummy }\end{array}$ & $\begin{array}{l}-0.192 \\
{[0.14]}\end{array}$ & $\begin{array}{l}-3.115 \\
{[2.21]}\end{array}$ & $\begin{array}{c}1.77 \\
{[5.65]}\end{array}$ & $\begin{array}{l}-0.167 \\
{[0.17]}\end{array}$ & $\begin{array}{l}0.0937 \\
{[0.23]}\end{array}$ & $\begin{array}{c}-0.15 \\
{[0.084]}\end{array}$ & $\begin{array}{l}-0.187 \\
{[0.12]}\end{array}$ & $\begin{array}{l}-0.291 \\
{[0.15]}\end{array}$ & \\
\hline French Revolution & 0.008 & -0.773 & 4.826 & 0.02 & 0.46 & $(0.01)$ & 0.01 & -0.113 & 0.195 \\
\hline x 1800 year dummy & {$[0.15]$} & {$[2.37]$} & [4.69] & {$[0.18]$} & {$[0.34]$} & {$[0.15]$} & {$[0.14]$} & {$[0.18]$} & {$[0.18]$} \\
\hline French Revolution & 0.187 & 3.807 & 4.664 & 0.21 & 0.71 & 0.17 & 0.15 & 0.072 & 0.333 \\
\hline x 1850 year dummy & {$[0.15]$} & {$[2.26]$} & {$[4.60]$} & {$[0.18]$} & {$[0.34]$} & {$[0.17]$} & {$[0.13]$} & {$[0.18]$} & {$[0.14]$} \\
\hline French Revolution & 0.712 & 12.52 & 9.745 & 0.774 & 1.32 & 0.67 & 0.672 & 0.621 & \\
\hline x 1875 year dummy & {$[0.20]$} & {$[3.06]$} & [4.83] & {$[0.25]$} & {$[0.38]$} & {$[0.18]$} & {$[0.14]$} & [0.14] & \\
\hline French Revolution & 0.765 & 13.17 & 10.47 & 0.836 & 1.39 & 0.718 & 0.724 & 0.665 & \\
\hline x 1880 year dummy & {$[0.23]$} & [3.52] & [5.15] & {$[0.29]$} & {$[0.38]$} & {$[0.18]$} & {$[0.18]$} & {$[0.16]$} & \\
\hline French Revolution & 0.81 & 13.23 & 11.33 & 0.901 & 1.451 & 0.757 & 0.769 & 0.693 & \\
\hline x 1885 year dummy & {$[0.26]$} & {$[3.90]$} & [4.99] & {$[0.31]$} & {$[0.40]$} & {$[0.16]$} & {$[0.23]$} & [0.19] & \\
\hline French Revolution & 0.85 & 13.44 & 11.83 & 0.95 & 1.508 & 0.792 & 0.808 & 0.725 & \\
\hline x 1890 year dummy & [0.29] & [4.38] & [5.33] & {$[0.35]$} & [0.41] & {$[0.16]$} & {$[0.27]$} & {$[0.22]$} & \\
\hline French Revolution & 0.864 & 13.13 & 12.42 & 0.99 & 1.538 & 0.8 & 0.821 & 0.717 & \\
\hline x 1895 year dummy & {$[0.33]$} & [4.77] & {$[5.65]$} & {$[0.38]$} & {$[0.43]$} & [0.15] & {$[0.31]$} & {$[0.27]$} & \\
\hline French Revolution & 0.988 & 14.56 & 14.01 & 1.044 & 1.678 & 0.919 & 0.945 & 0.905 & 1.098 \\
\hline x 1900 year dummy & {$[0.37]$} & [5.41] & [6.45] & {$[0.46]$} & {$[0.44]$} & {$[0.24]$} & {$[0.38]$} & {$[0.25]$} & [0.59] \\
\hline French Revolution & 1.063 & 15.22 & 15.04 & 1.165 & 1.769 & 0.988 & 1.019 & 0.925 & \\
\hline x 1905 year dummy & {$[0.36]$} & [5.29] & [6.24] & {$[0.42]$} & {$[0.47]$} & {$[0.17]$} & {$[0.39]$} & {$[0.28]$} & \\
\hline French Revolution & 1.075 & 14.92 & 15.72 & 1.168 & 1.798 & 0.994 & 1.03 & 0.952 & \\
\hline x 1910 year dummy & [0.37] & [5.39] & [6.23] & [0.43] & {$[0.50]$} & {$[0.19]$} & [0.42] & [0.29] & \\
\hline ControlXtime trend & & & & & 88.96 & 32.23 & 2.166 & & \\
\hline & & & & & [75.2] & [11.1] & [7.21] & & \\
\hline ControlXtime trendXpost- 1800 & & & & & -1.321 & -0.892 & 0.246 & & \\
\hline & & & & & [2.21] & {$[0.50]$} & {$[0.21]$} & & \\
\hline Lagged dependent variable & & & & & & & & & $\begin{array}{c}0.201 \\
{[1.42]}\end{array}$ \\
\hline $\begin{array}{l}\text { p-value for joint significance } \\
\text { "French Revolution" after } 1800\end{array}$ & 0.000 & 0.000 & 0.036 & 0.000 & 0.000 & 0.000 & 0.000 & 0.000 & 0.059 \\
\hline Definition of treatment & $\begin{array}{l}\text { Years of } \\
\text { French } \\
\text { Presence }\end{array}$ & $\begin{array}{l}\text { French Rev. } \\
\text { Armies } \\
\text { Dummy }\end{array}$ & $\begin{array}{l}\text { Napoleonic } \\
\text { Control } \\
\text { Dummy }\end{array}$ & $\begin{array}{l}\text { Years of } \\
\text { French } \\
\text { Presence }\end{array}$ & $\begin{array}{l}\text { Years of } \\
\text { French } \\
\text { Presence }\end{array}$ & $\begin{array}{l}\text { Years of } \\
\text { French } \\
\text { Presence }\end{array}$ & $\begin{array}{l}\text { Years of } \\
\text { French } \\
\text { Presence }\end{array}$ & $\begin{array}{l}\text { Years of } \\
\text { French } \\
\text { Presence }\end{array}$ & $\begin{array}{l}\text { Years of } \\
\text { French } \\
\text { Presence }\end{array}$ \\
\hline Control & N & N & $\mathrm{N}$ & $\mathrm{N}$ & Protestant & Latitude & $\begin{array}{c}\text { Initial } \\
\text { Urbanization }\end{array}$ & $\mathrm{N}$ & $\mathrm{N}$ \\
\hline Observations & 94 & 94 & 94 & 82 & 94 & 94 & 94 & 94 & 22 \\
\hline Countries & 8 & 8 & 8 & 7 & 8 & 8 & 8 & 8 & 8 \\
\hline R-squared & 0.96 & 0.95 & 0.95 & 0.95 & 0.96 & 0.97 & 0.96 & 0.96 & \\
\hline
\end{tabular}

Notes: Urbanization data for 8 pre-unitary German territories; all regressions have full set of country and year dummies. Robust standard errors, clustered by territory. 
Table 9

Within-Germany Impact of French Revolution: Urbanization in 8 reaions

Dependent variable: Urbanization (Percent living in cities above 5000 inh.)

Fixed Effects,

Weighted

Fixed Effects west of Elbe overid overid Fixed Effects Fixed Effects Fixed Effects Fixed Effects

$(2) \quad(3) \quad(4)$

(5)

(6)

Panel A: OLS estimation

0.368

0.419

0.368

0.419

0.376
$[0.13]$

$[0.13] \quad[0.15] \quad[0.13]$

0.419
$[0.15]$

[0.13]

0.295

[53.9]

[0.17]

28.84

[16.1]

$-1.109$

[0.59] (7)

ControlXtime trendXpost- 1800

[2.56]

0.345

[0.14]

2.704

[7.03]

0.166

[0.34]

\begin{tabular}{|c|c|c|c|c|c|c|c|c|}
\hline Panel B: First stage & & & & & & & & \\
\hline $\begin{array}{l}\text { Years of French Presence } \\
x \text { post } 1800 \text { dummy } x \text { time trend }\end{array}$ & $\begin{array}{l}0.711 \\
{[0.25]}\end{array}$ & $\begin{array}{l}0.878 \\
{[0.24]}\end{array}$ & & & $\begin{array}{l}0.698 \\
{[0.46]}\end{array}$ & $\begin{array}{l}0.658 \\
{[0.21]}\end{array}$ & $\begin{array}{c}0.7 \\
{[0.27]}\end{array}$ & $\begin{array}{l}0.603 \\
{[0.32]}\end{array}$ \\
\hline ControlXtime trend & & & & & -22.57 & 19.96 & 0.33 & \\
\hline & & & & & [61.4] & [15.4] & [3.30] & \\
\hline ControlXtime trendXpost- 1800 & & & & & 1.355 & 0.564 & 0.175 & \\
\hline & & & & & {$[6.62]$} & {$[1.58]$} & {$[0.65]$} & \\
\hline Panel C: 2SLS estimation & & & & & & & & \\
\hline Reforms Index & 0.658 & 0.575 & 0.693 & 0.608 & 0.916 & 0.659 & 0.636 & 0.741 \\
\hline & {$[0.21]$} & [0.17] & {$[0.21]$} & {$[0.18]$} & {$[0.50]$} & {$[0.23]$} & {$[0.21]$} & [0.24] \\
\hline ControlXtime trend & & & & & 15.23 & 22.07 & 2.678 & \\
\hline & & & & & {$[60.5]$} & [15.8] & [6.04] & \\
\hline ControlXtime trendXpost- 1800 & & & & & 3.471 & -1.464 & 0.0823 & \\
\hline & & & & & [6.68] & {$[0.91]$} & {$[0.50]$} & \\
\hline $\mathrm{p}$-value overidentification test & & & 0.529 & 0.428 & & & & \\
\hline Control & $\mathrm{N}$ & $\mathrm{N}$ & $\mathrm{N}$ & $\mathrm{N}$ & Protestant & Latitude & $\begin{array}{c}\text { Initial } \\
\text { Urbanization }\end{array}$ & $\mathrm{N}$ \\
\hline Number of Countries & 8 & 7 & 8 & 7 & 8 & 8 & 8 & 8 \\
\hline Number of Observations & 94 & 82 & 94 & 82 & 94 & 94 & 94 & 94 \\
\hline
\end{tabular}

Notes: Urbanization data for 8 pre-unitary German territories; all regressions have full set of country and year dummies. Robust standard errors, clustered by territory. The overidentification test in columns 3 and 4 uses robust standard errors. 
Table 10

Within-Germany Impact of French Revolution: Railways

\begin{tabular}{|c|c|c|}
\hline \multirow[t]{2}{*}{ Dependent variable: } & \multicolumn{2}{|c|}{$\log (\mathrm{km}$ of railways) } \\
\hline & $\begin{array}{c}\text { baseline } \\
(1)\end{array}$ & $\frac{\text { west of Elbe }}{(2)}$ \\
\hline \multicolumn{3}{|c|}{ Cross-sections, impact of the French Revolution } \\
\hline in 1859 & $\begin{array}{c}-0.015 \\
{[0.014]}\end{array}$ & $\begin{array}{c}-0.001 \\
{[0.038]}\end{array}$ \\
\hline in 1864 & $\begin{array}{l}-0.001 \\
{[0.014]}\end{array}$ & $\begin{array}{c}0.01 \\
{[0.039]}\end{array}$ \\
\hline in 1869 & $\begin{array}{c}0.004 \\
{[0.017]}\end{array}$ & $\begin{array}{c}0.026 \\
{[0.040]}\end{array}$ \\
\hline in 1874 & $\begin{array}{c}0.000 \\
{[0.016]}\end{array}$ & $\begin{array}{c}0.012 \\
{[0.030]}\end{array}$ \\
\hline in 1880 & $\begin{array}{c}0.037 \\
{[0.015]}\end{array}$ & $\begin{array}{c}0.057 \\
{[0.018]}\end{array}$ \\
\hline in 1885 & $\begin{array}{c}0.036 \\
{[0.014]}\end{array}$ & $\begin{array}{c}0.056 \\
{[0.016]}\end{array}$ \\
\hline in 1890 & $\begin{array}{c}0.034 \\
{[0.013]}\end{array}$ & $\begin{array}{c}0.056 \\
{[0.016]}\end{array}$ \\
\hline in 1895 & $\begin{array}{c}0.030 \\
{[0.013]}\end{array}$ & $\begin{array}{c}0.051 \\
{[0.015]}\end{array}$ \\
\hline in 1900 & $\begin{array}{c}0.088 \\
{[0.029]}\end{array}$ & $\begin{array}{c}0.134 \\
{[0.034]}\end{array}$ \\
\hline in 1905 & $\begin{array}{c}0.090 \\
{[0.029]}\end{array}$ & $\begin{array}{c}0.136 \\
{[0.035]}\end{array}$ \\
\hline in 1910 & $\begin{array}{c}0.089 \\
{[0.029]}\end{array}$ & $\begin{array}{c}0.135 \\
{[0.035]}\end{array}$ \\
\hline
\end{tabular}

Notes: Each cell corresponds to one cross-sectional regression.

Impact of the French Revolution is measured in Years of

French Control. Robust standard errors, clustered by state.

Data are for Prussia only until 1874 , for provinces and states

Only arter 1895

1895), 38/27 (after 1895).
Table 11

Within-Germany Impact of French Revolution: Occupational shares

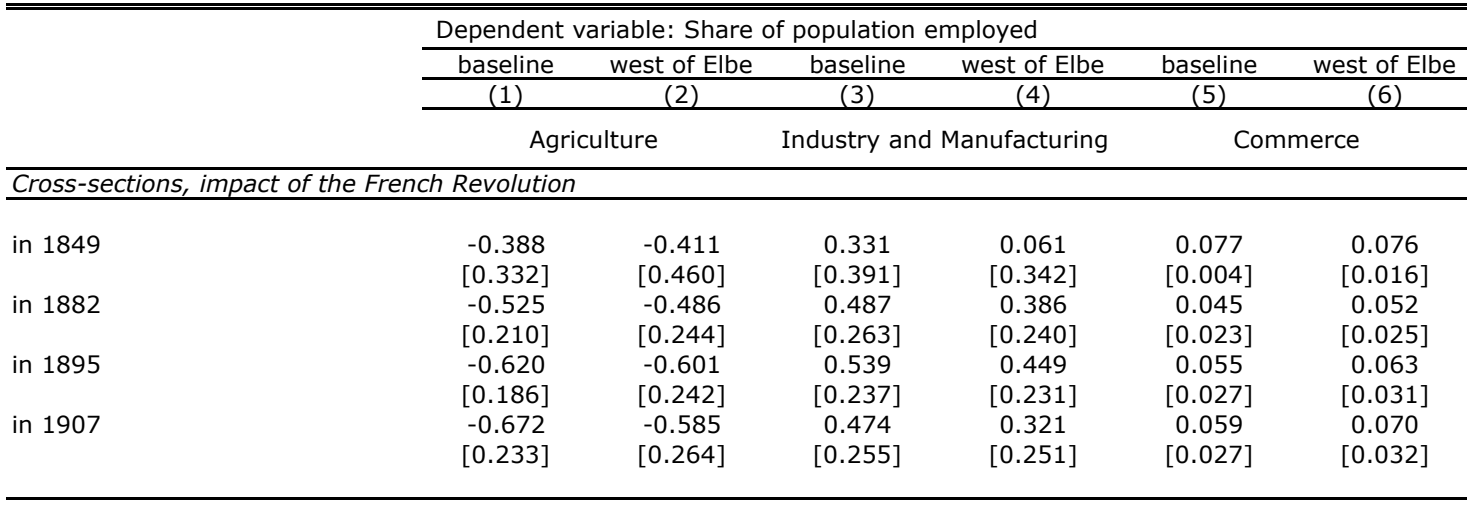

Notes: Each cell corresponds to one cross-sectional regression. Impact of the French Revolution is measured in Years of French Control. District level data. Robust standard errors, clustered at the state level. Number of observations

(baseline/west of Elbe): 39/23 (1849), 62/44 (other years). 